\title{
International Parental Child Abduction and Mediation
}

\section{Sustracción internacional de menores y mediación}

\author{
Nuria González Martín* \\ Sumario: I. Introduction. II. The 1980 Hague Child Abduction Conven- \\ tion. III. Guide to Good Practice on Mediation. IV. International Family \\ Mediation: Challenges and Specialized Necessity. V. Conclusions.
}

* $\quad \mathrm{PhD}$ in Private International Law, Pablo de Olavide University, Seville, Spain. DEA (LLM) in Law, Seville University. Bachelor's degree, Law, Seville University. Senior Researcher, Institute for Legal Research, National Autonomous University of Mexico (UNAM). Visiting Scholar, Stanford Law School 2012-2013 and CISAC- Stanford University 2013-2014. External counselor to Mexico's Foreign Affairs Ministry on Private International Law. Family, civil and commerce law mediator, certified by Mexico City's Supreme Court. Editor in Chief, "Boletín Mexicano de Derecho Comparado". Member of a wide diversity of associations such as: International Academy of Comparative Law (IACL), Mexican Academy of Sciences (AMC), General Secretary at American Association of Private International Law (ASADIP) and the Mexican Academy of Private International and Comparative Law (AMEDIP), coordinator of the Commission for the international child protection of the National Illustrious Attorney College of Mexico (INCAM), Spanish Association of International Law and International Relations Professors (AEPDIRI) and the Spanish, Portuguese and American Institute for International Law (IHLADI).

In this article we mentioned several examples about the United States of America and Mexico, the reason is because this research was done during a sabbatical year at Stanford Law School and under the sponsorship of DGAPA, UNAM.

I wish to acknowledge and thank Mariano-Florentino Cuéllar (Director of Stanford's Freeman Spogli Institute for International Studies and Stanley Morrison Professor of Law at Stanford Law School), Janet Martinez (Director Martin Daniel Gould. Conflict Resolution Programs at Stanford Law School) for their support and encouragement regarding this project; To Colin Rule, my “officemate”, for his kindness and his willingness to help me contact key experts in the subject. Melissa Kucinski for her feedback and for providing me access to international family mediation in the USA. Manuel A. Gómez, Professor at Florida International University, College of Law, a true friend and a knowledgeable one too to Sergio Stone and George Wilson for his support at the Library. I wish to thank as well all our friendly readers and authors who have contributed directly and indirectly in the making of this text. To my friends, The Ladies, because they are wonderful and last but not least, to Antonio, Nuria and Pablo always with all my heart.

Artículo recibido el 6 de febrero de 2014 Aprobado para publicación el 24 de septiembre de 2014 
ABSTRACT: The goal of this article is, first, to analyze the operation of the Hague Convention of 25 October 1980 on the Civil Aspects of International Child Abduction in the context of its Guide to Good Practice on Mediation to determine whether such guide will promote Mediation as a useful method for family conflict resolution in cases of international child abduction by one of the parents. Secondly we aim to explore current efforts to ensure that parents have the opportunity to choose mediation voluntarily with a skilled international family mediator to resolve issues between the left-behind parent and the taking parent and, why not, the child or children. The use of advanced technological tools in these cases is evaluated.

Key words: International parental child abduction, mediation, international family mediation, alternative disputes resolution, wrongful removal, wrongful retention, habitual residence, left-behind parent, taking parent, Guide to Good Practice, Hard Law, Soft Law

Resumen: El objetivo de este artículo es, primero, analizar la operatividad de la Convención de 25 de octubre de 1980 sobre los aspectos civiles de la sustracción internacional de menores en el contexto de la Guía de Buenas Prácticas en Mediación para determinar si tal Guía puede promover la mediación como un método útil para la resolución de conflictos familiares en materia de sustracción parental internacional de menores. En segundo lugar, nos proponemos explorar los actuales esfuerzos para asegurar que los padres tengan la oportunidad de elegir la mediación voluntaria con un mediador familiar internacional especializado para resolver problemas entre el padre perjudicado y el padre sustractor y, por qué no, el niño o los niños. Se evalúa, asimismo, el uso de herramientas tecnológicas avanzadas en estos casos.

Palabras clave: Sustracción parental internacional de menores, mediación, mediación familiar internacional, medios alternos de solución de disputas, traslado ilícito, retención ilícita, residencia habitual, padre perjudicado, padre sustractor, guía de buenas prácticas, Hard Law, Soft Law.

RÉsumÉ: Le but de cet article, qui est tout d'abord d'analyser les opérations de la Convention de Hague du 25 Octobre 1980 sur les Aspects Civils de l'Enlèvement International d'Enfants dans le contexte du Guide des Bonnes Pratiques sur la Médiation - pour déterminer si ce guide encourage la Médiation comme une méthode utile pour la résolution du conflit familiale dans le cas d'enlèvement parental international d'un enfant par un des parents. Deuxièmement, on vise a explorer les efforts actuels pour s'assurer que les parents ont l'opportunité de choisir volontairement un médiateur familial international spécialisé dans la résolution des problems entre le parent délaisse et celui qui a enlevé l'enfant, et meme pourquoi pas l'enfant ou les enfants aussi. L'utilisation des outils technologiques avances est évaluée dans tous ces cas.

Mots-clés: l'Enlèvement International d'Enfants, Médiation, la médiation familiale internationale, modes alternatifs de règlement des différends, transfert illicite, detainer illégale, résidence habituelle, père blessé, parent ravisseur, Guide des bonnes pratiques, Hard Law, Soft Law. 


\section{INTRODUCTION}

The future but, first or most importantly, the present of our children depends on their wholesome and healthy development within a family unit.

When we talk about family, we are referring to a variety of family structures ${ }^{1}$ obviously including those where there is a separation or divorce and the involvement of both parents with their children should be a top priority, but reality is not so in many cases.

We should not forget that while we can have ex-husbands or ex-wives, there never will be ex-fathers or ex-mothers. The emotional, physical and economic children's care must be taken into consideration by both parents when the dissolution takes place.

In this context, international child abduction, usually by one of the parents, is a current and relevant topic due to the considerable increase in the number of cases detected. International parental child abduction generally refers to the "wrongful removal" or "wrongful retention" to another country of a child by the child's parent or guardian. ${ }^{3}$ This problem may be growing due to several factors such as:

1) The internationalization of family relations. ${ }^{4}$

1 González Martín, N., "Modelos familiares ante el nuevo orden jurídico: una aproximación casuística”, en Carbonell, J. (ed.), Las familias en el siglo XXI: una mirada desde el derecho, México, UNAM, 2012.

2 Article 3 of the Hague Convention of 25 October 1980 on the Civil Aspects of International Child Abduction expresses "The removal or the retention of a child is to be considered wrongful where:

a) it is in breach of rights of custody attributed to a person, an institution or any other body, either jointly or alone, under the law of the State in which the child was habitually resident immediately before the removal or retention; and $b$ ) at the time of removal or retention those rights were actually exercised, either jointly or alone, or would have been so exercised but for the removal or retention)".

3 In a small number of cases within the scope of the 1980 Convention it is a person other than he parent (a grandparent a step-parent or any other related or unrelated person) or an institution or other body whose custody rights are breached by a wrongful removal or retention of the child. Guide to Good Practice under the Hague Convention of 25 October 1980 on the Civil Aspects of International Child Abduction. Mediation. SI, 2012/11.

4 The economic globalization imply, also, an expansion of international travel and tourism and these increase a bi-national marriages, for example. 
2) The crisis of family as an institution, and more specifically of marriage as an institution, as well as the increasing number of crisis among couples.

3) The increase in conflicts arising from the dissolution of marital or sentimental ties when children exist.

The battle that arises as the couple breaks up, and the use and manipulation of children as weapons, leads to an increase in abduction situations that inflicts a permanent damage upon minors. ${ }^{5}$ The children involved in parental abduction, are victims of their parents' war.

This is why the key concepts are always to be kept in mind, such as the best interests of the child, which is the fundamental principle upon which article 3 of the United Nations Convention on The Rights of the Child (UNCRC) ${ }^{6}$ is based, ${ }^{7}$ likewise, we have the "child's right to maintain on a regular basis... personal relations and direct contacts with both parents" as guaranteed by article 10.2 UNCRC. ${ }^{8}$ Another equally outstanding matter is the principle stating the minor's right to be listened to in all cases with a general character and without exceptions, (art. 12UNCRC) ${ }^{9}$ and to this

5 The psychological harm suffered by abducted children is of unfathomable proportions. S Reynolds, "International Parental Child Abduction: Why We Need to Expand Custody Rights Protected Under the Child Abduction Convention" (2006) 44 Fam. Ct. Rev. 464, 466. Not to mention issues that arise, such as the parental alienation syndrome. N González Martín, "Convivencia Paterno/Materno Filial en el Panorama Internacional: Un Acercamiento en Torno a la Sustracción de Menores, Alienación Parental y Mediación Familiar Internacional”, en Alienación Parental y Derechos Humanos, (México, CNDH, 2008) 9, 52.

6 Article 3.1 UNCRC express "In all actions concerning children... the best interest of the child shall be a primary consideration”. http://www.ohchr.org/english/law/crc.htm, accessed on November 9, 2013.

7 We notice that the doctrine expressing the best interest of the child is not a predominant rule except in adoption cases (article 21 UNCRC) or when children are separated from their parents (article 9 UNCRC). In this context see the Directrices of ACNUR (International Social Service, 10/2008) and the General Observation Committee UNCRC, International Social Service, Boletín Mensual núm. 01/2013, enero 2013, p. 1 and ss. González Martín, N., "Presentación” en González Martín, N. (coord.), Temas de Actualidad Jurídica sobre la Niñez, México, Porrúa, 2012.

8 United Nations Convention of 20 November 1989 on the Rights of the Child, article 10 (2), http: / / www.ohchr.org/english/law/crc.htm accessed on November 9, 2012.

9 Forcada, F. J., “Capítulo décimo tercero, derecho del niño a ser oído”, en Tenorio, L. (coords.), La restitución internacional de la niñez. Enfoque iberoamericano, doctrinario y jurispruden- 
end, a more adequate legal framework must be fostered. A caveat regarding this giving voice to, or listening to the child: it is always important to bear in mind that the will of the child should not be considered, the single decisive element for a judge to reach a resolution, and this will be reinforced in the next section, dedicated to laying the foundations of how International parental Child abduction should be addressed. That is how the judicial power has manifested itself most frequently, which is why a number of similar sentences can be found. ${ }^{10}$

However, the fact that resolutions may not be reached on the right grounds makes it particularly important that progress is made towards prevention, and research of mechanisms that help detect and stop International child abduction by one of the parents.

In this context, in a dispute arising out of a parental separation, concretely in cross-border family disputes over custody and contact, for instance, it is also very important to promote agreements. There is a growing use of mediation and similar processes facilitating the amicable resolution of disputes in family law. ${ }^{11}$ This highlights the relevance of bringing about agreed solutions in family disputes, through a process like mediation between the left-behind parent ${ }^{12}$ and the taking parent ${ }^{13}$ that allow a child to

cial, México, Porrúa, 2011, pp. 246 y 265. In the specific case of international parental child abduction the question arises as to whether the child should be involved in the mediation, and if so, what is the best way to do so.

10 Take for instance the case of Argentina's supreme court in 2012 when expressing:

"VI.- en el marco convencional, la ponderación de la opinión del niño no pasa por la indagación de su voluntad de vivir con uno $u$ otro de los progenitores.

VII.- en razón de su singular finalidad, el CH 1980 no adhiere a una sumisión irrestricta respecto de los dichos del niño involucrado. Por el contrario, la posibilidad del arto 13 (penúltimo párrafo) sólo se abre frente a una voluntad cualificada, que no ha de estar dirigida a la tenencia o a las visitas, sino al reintegro al país de residencia habitual; $y$, dentro de esta área puntual, no ha de consistir en una mera preferencia o negativa, sino en una verdadera oposición, entendida como un repudio irreductible a regresar". Fallo de la Corte Suprema de Justicia de la Nación del 22/8/12: "G., P. C. el H., S. M. s/ reintegro de hijo”. Extracto Dictamen Sra. Procuradora Fiscal, p. 9.

11 Guide to Good Practice under the Hague Convention of 25 October 1980 on the Civil Aspects of International Child Abduction. Mediation. SI 2012/21. http: / / www.hcch.net.

12 The term "left-behind parent" or "searching parent" refers to the parent who claims that his/her custody rights were breached by a wrongful removal or retention (Article 3 of the 1980 Hague Child Abduction Convention).

13 The term "taking parent", "kidnapping parent" or "parental kidnapper" refers to the parent who is alleged to have wrongfully removed a child from his/her place of habitual residence to another State or to have wrongfully retained a child in another State. 
carry on with his life in a stable environment. We consider that Alternative Dispute Resolution (ADR) methods, such as mediation, are the best tools available in these cases. This becomes apparent when one considers the recent growth of legal initiatives related to children and the growing emphasis on mediation in resolving international child abduction cases.

Therefore, the goal of this article is, first, to analyze or review the operation of the Hague Convention of 25 October 1980 on the Civil Aspects of International Child Abduction in the context of its Guide to Good Practice on Mediation, that is, to determine whether such guide will promote Mediation as a useful method for family conflict resolution in cases of international child abduction by one of the parents.

In the same context, the second goal of this paper will be to explore current efforts to ensure parents have the opportunity to elect voluntary mediation with a skilled international family mediator to resolve issues between the left-behind parent and the taking parent as well as those related to the child or children and the use of technology tools in these cases.

\section{The 1980 Hague Child Abduction Convention}

In 2013, we are celebrating the $30^{\text {th }}$ anniversary of the entry into force of the Hague Convention on the Civil Aspects of International Child Abduction $^{14}$ (The 1980 Hague Convention or The 1980 Hague Child Abduction Convention), a treaty that has facilitated "the prompt return of children wrongfully removed to, or retained in any Contracting State", that is, the prompt return of the child to his or her habitual residence ${ }^{15}$ - so that a

14 The Hague Convention of 25 October 1980 on the Civil Aspects of International Child Abduction, into in force, SI/1983. Nations acceding to the Convention following signing in 1980 must be approved and ratified by other Member States. This Convention will have effect only between the acceding State and such Contracting States as will have declared their acceptance of the new acceding State.

15 For this topic see Beaumont, Paul R. and McEleavy Peter E., The Hague Convention on International Child Abduction, UK, Oxford University Press, 1999, esp. pp. 88 and ss.; McEleavy, Peter, "The New Child Abduction Regime in the European Union: Symbiotic Relationship or Forced Partnership?", Journal of Private International Law, vol. I, no. I, april 2005; McEleavy, 
court of that country can resolve issues of custody and visitation - ${ }^{16}$ yet the treaty is by no means perfect ${ }^{17}$ maybe because we have not fully understood yet that there is a basic principle to embrace, meaning the best interest of the child, which concerning child abduction, consists in respecting and guaranteeing the full exercise of his rights, and that, regarding the 1980 Hague Convention, means his right not to be removed or wrongfully withheld, and if need be, to a rapid return ${ }^{18}$ as well as a safe one. If any of the exceptions considered in the 1980 Hague Convention were applicable,

Peter, "Evaluating the Views of Abducted Children: Trends in Appellate Case-Law", Child and Family Law Quarterly, vol. 20, no. 2, 2008.

The 1980 Hague Convention proceeding is whether the child was "habitually resident in a Contracting State". The Convention is silent as to the definition of place of habitual residence. "This silence is thought to be deliberate, «the aim being to leave the notion free from technical rules, which can produce rigidity and inconsistencies as between legal systems» [Isaac v. Rice, 1998 U.S. Dist. LEXIS 12602]. The term is interpreted from the child's perspective [Friedrich v. Friedrich, 983 F. 2d 1396, 1401 ( $6^{\text {th }}$ Cir. 1993)] and considers whether the child has been taken out of the family and social environment in which his or her life has developed" Cit. per M Walsh, "International Child Abduction and the Hague Convention" (2006) 6 Barry Law Rev. 32. González Martín, N., "Relatoría de la Sexta Reunión de la Comisión Especial Sobre el Funcionamiento Práctico del Convenio de La Haya de 1980 Sobre los Aspectos Civiles de la Sustracción Internacional de Menores y del Convenio de La Haya de 1996 Relativo a la Competencia, Ley Aplicable, Reconocimiento, Ejecución y Cooperación en Materia de Responsabilidad Parental y de Medidas de Protección de los Niños, La Haya, Holanda, 1-10 Junio 2011”, Anuario Mexicano de Derecho Internacional, no. XII, 2012.

16 The 1980 Hague Convention: Article 16, "After receiving notice of a wrongful removal or retention child in the sense of Article 3, the judicial or administrative authorities of the Contracting State to which the child has been removed or in which it has been retained shall not decide on the merits of rights of custody until it has been determined that the child is not to be retuned under this Convention or unless an application under this Convention is not lodged within a reasonable time following receipt of the notice".

17 Zawid, J., "Practical and Ethical Implications of Mediating International Child Abduction Cases: A New Frontier for Mediators", 1 The University of Miami Inter-American Law Review, 2, 2008.

18 "The requirement that the child be returned promptly is crucial for three reasons: First, it is a resasonable assumption that it is generally better for the child if any disruption caused by an abduction is resolved as quickly as possible... Secondly, the longer the child is away from their State of habitual residence, the more likely they are to become settled in their new environment... Thirdly, one of the aims of the 1980 Convention is to deter abductions". Therefore, timing is key to the successful operation of the 1980 Convention. Lowe, N., The Timing of 1980 Hague Abduction Convention Applications: the 2011 Findings, Nuffield Foundation, Cardiff Law School, 2012, p. 3. 
the return must be denied in order to protect the Child's best interest, although the court has discretion. Likewise, such principle entails the right to visit the parent who does not live with the child, and his relatives, as well as adequate access to justice ${ }^{19}$ in a broader sense.

Now, 30 years later, we have an opportunity to revise the practical operation of such convention and how it adapts to everyday reality, "In particular, the international child-welfare community is calling for an enhanced role of mediation in international parental abduction proceedings". ${ }^{20}$

On one hand, the existence of a pre-litigation child or an international family mediation can even prevent an international child abduction case to be brought to court $\mathrm{t}^{21}$ under the requirements of the Hague Convention, that is, the child must be under the age of sixteen and the removal or retention of the child, generally by one their parents, must be "wrongful", ${ }^{22}$ i.e. "breaching the other parent's rights of custody", only a breach of rights of custody will invoke the 1980 Hague Convention's return remedy, the return remedy is not available when only "rights of access" have been violated. ${ }^{23}$

19 Pérez, R., "El interés superior del niño en el convenio de la Haya de 1980. Orientaciones para su interpretación”, 56 Revista de Derecho de Familia, 237.

20 Zawid, supra n. 19, 3.

21 Even a mediator may be working parallel to the legal frameworks in place between the two implicated countries or maybe trying to prevent the parents from starting these lengthy legal processes. Moreover "In order to be successful, a mediation program must account for the pre-mediation process, such as determining a case's suitability for mediation...”. Kucinsky, M. A., "Creating a Successful Structure to Mediate International Parental Child Abduction Cases” (2012) 26 American Journal of Family Law, 83.

22 The 1980 Hague Convention will not govern wrongful removal occurring prior to accession and ratification.

23 It is important to notice that the Convention differentiates between custody rights and access rights. Access rights refer to the right to take a child to a place other than the child's habitual residence for a period of time upon which the parents have mutually agreed — article 21 of the Convention - . Custody rights may arise by operation of law, by judicial or administrative decision, or by an agreement that has legal effect and it is specifically defined within the Convention as "rights relating to the care of the person of the child and, in particular, the right to determine the child's place of residence" - article 5 the 1980 Hague Convention-. Having mentioned this, we need to highlight that it is important to separate Convention concepts from domestic analogues found in particular judicial systems. Walsh, supra n. 15, 35. Another think is the narrowly interpreted access rights for the Hague Conference.

About the interpretation "rights of custody" see Silverman, L. J., "Abbott v. Abbott: U.S. Supreme Court Opinion on Whether ne exeat Rights Create 'Rights of Custody' in favor of noncustodial parents under the Hague Convention on the Civil Aspects of Child Abduction: Convention on the Civil Aspects of International Child Abduction — Custody Rights — ne 
On the other hand, the Hague Convention provides defenses or exceptions to the return of the child to his habitual residence, once a petitioner demonstrates that the removal or retention of the child was wrongful, ${ }^{24}$ when:

1) the person requesting removal was not, at the time of the retention or removal, actually exercising custody rights, or had consented to, or subsequently acquiesced in, the removal or retention (article 13 (a));

2) the return would result in great risk of physical or psychological harm (article $13(\mathrm{~b})) ;^{25}$

3) the child's return would not be permitted by the fundamental principles of the requesting State relating the protection of human rights and fundamental freedoms (article 20);

4) the return proceedings commenced more than one year after the abduction and the child has become settled in the new environment (article 12$)^{26}$ and

5) the child objects to being returned and has attained an age and degree of maturity at which it is appropriate to take into account his or her views. Such exceptions may become a double edge sword if inappropriately used, as we shall see further in this text. ${ }^{27}$

exeat Rights", American Journal of International Law, USA, January 2011, 108-114; Pachter, E., "Abbott v. Abbott: An Overly Broad Conclusion as to Whether Ne Exeat Provisions Create Rights of Custody Under the Hague Convention on the Civil Aspects of International Child Abduction”, Maryland Journal of International Law, USA, vol. 27, 2012, 355-376.

24 With regard to exceptions, the Child's best interest interpretation to the extent that it is the abducting parent who must demonstrate and provide evidence of the existence of the exception invoked. According to Pérez Manrique, even once the risk has been demonstrated, for instance in cases of domestic violence, it must be verified that such risk cannot be controlled or averted in the country of habitual residence of the child. A correct and harmonious interpretation of the Child's best interest will prevent invoking exceptions from becoming a shortcut to avoiding returns. Pérez, supra n. 20, 241.

25 The "grave risk" (based, generally, in domestic violence) exception found under this article 13 (b) is the most frequently asserted defense in application cases.

26 This exception is intended to protect the child when the left-behind parent does not swiftly act to pursue return and the child has acclimated to his new surroundings. Pérez Vera, E., "Explanatory Report, Convention on the Civil Aspects of International hild Abduction, Hague Conference on Private International Law”, 426 III Actes et Documents de la Quartorzieme, 1980 , p. 458.

27 Walsh, supra n. 15, 50; J Lewis, "The Hague Convention on the Civil Aspects of International Child Abduction: When Domestic Violence and Child Abuse Impact the Goal of Comity" (2000) 13 Transnat'l Law, 391, 400. 
In order to clarify all these situations involving displacements, retentions and exceptions, data is required, but there are actually no available statistics that accurately capture the number of international parental abductions every year. ${ }^{28}$ The Hague Conference on Private International Law through his Permanent Bureau maintains case statistics on disputes brought under the 1980 Hague Child Abduction Convention based on the information reported by Central Authorities of states party ${ }^{29}$ without the number of dispute cases involving a non state party, for instance. ${ }^{30}$

The case of the United States is unique, since most available data suggests that more children are abducted into or out of the United States than any other party State to the Hague Convention ${ }^{31}$ (particularly with Mexico). Actually, as expressed earlier, the reality is that most states do not maintain — current - international parental kidnapping statistics. The United States in 2007, the National Center for Missing and Exploited Children (NCMEC) maintained an average of more than 1,800 active international parental kidnapping cases — more than half of them involving Latin America-. 32

On April 1, 2008, the Office of Children's Issues, Central Authority in United State in cases of international abduction, assumed too the handling of all "incoming" Hague child abduction cases, that is, abductions of children to the United States from countries that are partners under the 1980 Hague Convention. ${ }^{33}$

28 Walsh, supra n. 15, 30.

29 INCASTAT is the statistics database of the Permanent Bureau's international child abduction http: / / www.hcch.net/index.en.php?act.

30 We can see with Lowe Nigel et al., a significant number of statistical analysis or applications: $50 \%$ of the applications, assuming the agreements or orders were actually enforced, ended in the return of the child; $32 \%$ of applications ended with a judicial return and $18 \%$ was the rate of voluntary returns. Lowe, Nigel et al, Statistical Analysis of Applications, http: / / www.ncmec.org, p. 13.

31 Lowe, N., Hague Conference on Private International Law, A Statistical Analysis of Applications Made in 2003 Under the hague Convention of 25 October 1980 on the Civil Aspects of International Child Abduction. Part I.National Reports 479 (2007 update) http://hcch.e-vision.nl/upload(wop/ abd_pd03ef2007.pdf.

32 Alanen, J., "When Human Rights Conflict: Mediating International Parental Kidnapping Disputes Involving the Domestic Violence Defense", The University of Miami Inter-American Law Review, 57 and Zawid, 2008, supra n. 17, 4.

33 http: / / travel.state.gov/abduction/about/whatsnew/whatsnew_3859.html (March 26, 2013) under "Possible Solutions-Using the Hague Abduction Convention". 
Focusing on the problems posed by the concrete case of Mexico and the United States, statistics of the Mexican Central Authority show that: ${ }^{34}$

- During 2010 there were in Mexico 221 new cases of international wrongful child removal or retention, with 310 minors involved.

- In 2010 there was in Mexico a total of 417 cases — some of which started in 2008 - and 337 of those cases is related directly or indirectly with the United States.

The United States Central Authority has shown that: ${ }^{35}$

- During 2010, 2011 and 2012, respectively, there were in the United States -outgoing case statistics- a total of 1022, 941 and 799 new cases of international wrongful child removal or retention, with 1492, 1367 and 1144 minor involved.

- In 2010, 2011 and 2012, respectively, there were in the U.S. - outgoing case statistics - a total of 329, 302 and 260 cases related to Mexico with 524, 465 and 416 minors involved.

Such figures already showed an important number of cases involving the United States and Mexico and some reasons for that are the intense contact and border crossing between the two countries, interpersonal relationships, the cultural difference, and the inevitable crisis of family as an institution. Nonetheless, a significant number of countries is analyzed. ${ }^{36}$

\section{GUide TO GoOd Practice ON MEDiation}

This subject, that is, the international parental child abduction has been addressed in a variety of international forums and now, due to its recent occurrence, it is pertinent to focus on the work conducted at the Hague Confe-

34 http://www.sre.gob.mx/index.php/oficinas-centrales/direccion-general-de-proteccion-a-mexica nos-en-el-exterior under Dirección de Familia accessed April 2013.

35 http: / / travel.state.gov/abduction/resources/resources_3860.html accessed March 2013.

36 http://travel.state.gov/abduction/about/whatsnew/whatsnew_3859.html accessed March 2013. 
rence on Private International Law, ${ }^{37}$ and the agenda of the Sixth Meeting ${ }^{38}$ of its Special Commission of June 2011 and January 2012, ${ }^{39}$ in which the practical operation of the 1980 Hague Convention on the Civil Aspects of International Child Abduction and The Hague Convention of 19 October 1996 on Jurisdiction, Applicable Law, Recognition, Enforcement and Co-operation in Respect of Parental Responsibility and Measures for the Protection of Children. ${ }^{40}$

Most of the last Hague Family Conventions explicitly encourage mediation and similar processes for finding appropriate solutions to cross-border family disputes and, concretely, Soft Law instruments are implemented. ${ }^{41}$

37 See in connection with the Hague's Conference of Private International Law, all instruments related to Hard Law and Soft Law. González Martín, N., Compatibilidad de las convenciones interamericanas y universales en materia de familia y niñez: evolución y análisis, Washington, D.C., OEA, 2011.

38 Previous meetings were held: First meeting of the special commission, October 1989; Second meeting on January 18-21 1993; Third meeting March 17-21 1997; Fourth, March 22-28 2001; Special Commission September-October 2002. Fifth October 30- November 9 2006. The sixth meeting took place in two different dates: (June 1-10, 2011 and January 2531, 2012 with 92 R\&C. www.hcch.net under "Child Abduction Section".

39 This way, emphasis is placed on the most specific, current and demanding issues related to putting into practice both of the conventions revise during the sixth meeting of the special commission (Part I: June 2011 - Part II: January 2012), i.e. both the 1980 and the 1996 Hague Conventions. Under such premises debate took place on the following topics (Part I): 1. Cooperation among central authorities designated for the 1980 Hague Convention; 2. Processing of restitution claims made by Central Authorities.; 3. The role played by Central Authorities regarding the 1996 Hague Convention. 4. Training and fraternization of Central Authorities for the 1980 and 1996 Hague Conventions 5. Meetings and On line collaboration of Central Authorities of the 1980 and 1996 Hague Conventions (use of Information Technologies); 6. Claims for visit/contact filed under the 1980 and 1996 Hague Conventions 7. Allegations of domestic violence and restitution procedures; 8. Issues concerning Access to justice and fair treatment; 9. Discussion about the related jurisprudence regarding the 1980 Hague; 10. The child's voice/opinion in the restitution process and other procedures. 11. Use of the Guides to Good Practice of the 1980 Hague Convention, Part III dedicated to Prevention Measures and Part IV dedicated to Execution. 12 Consideration of a Practical Draft for the 1996 Hague Convention. 13. Judicial network, and direct judicial communications. 14. Consideration of the Draft for a Guide to Good Mediation Practices related to the 1980 Hague Convention; 15. Mediation principles developed within the context of the Malta Process; 16. Protocol. In this respect, a chronicle can be found in: N. González Martín, supra n. 15.

40 Bear in mind that during the sixth meeting of the Special Commission both the 1980 Hague Convention as well as the 1996 Hague Convention on Parental Responsibility were analyzed. Due to the subject matter of this text, only a reference will be made to this contribution in aspects related to the first convention, i. e. The 1980 Hague Convention.

41 González Martín, N., "Private International Law in Latin America: from Hard to Soft Law” (2011) XI Anuario Mexicano de Derecho Internacional, 393-405; González Martín supra n. 37. 
Several of the Guides to Good Practice drafted to support the effective implementation and operation of the 1980 Hague Child Abduction Convention.

Thus, "mediation in cross-border family disputes in general has been discussed for many years as one of the topics of future work for the Hague Conference", ${ }^{42}$ for example:

- In April 2006, the Permanent Bureau of the Hague Conference was mandated by its Member States to "prepare a feasibility study on crossborder mediation in family matters, including the possible development of an instrument on the subject". ${ }^{43}$

- In April 2007, the Council decided to invite the Hague Conference Members to: "provide comments, before the end of 2007, on the feasibility study on cross-border mediation in family matters". ${ }^{4+}$

- -In April 2008, the Council: "invited the Permanent Bureau to continue to follow, and keep Members informed of, developments in respect of cross-border mediation in family matters" ${ }^{\prime 45}$ and asked to commence work of: "a Guide to Good Practice on the use of mediation in the context of the Hague Convention of 25 October 1980 on the Civil Aspects of International Child Abduction... to be submitted for consideration at the next meeting of the Special Commission to review the practical implementation of that Convention... in 2011". ${ }^{46}$

- -In March/April 2009, the Council: "reaffirmed its decision taken at the meeting of April 2008 in relation to cross-border mediation in fam-

42 Guide to Good Practice under the Hague Convention of 25 October 1980 on the Civil Aspects of International Child Abduction. Mediation. SI, 2012/14.

43 Conclusions of the Special Commission of 3-5 April 2006 on General Affrairs and Policy of the Conference. www.hcch.net under "Work in Progress" and "General Affairs", Recommendation No. 3 .

44 Recommendations and Conclusions adopted by the Council on General Affairs and Policy of the Conference (2-4 April 2007) www.hcch.net under "Work in Progress" and "General Affairs", Recommendation No. 3.

45 Recommendations and Conclusions adopted by the Council on General Affairs and Policy of the Conference (1-3 April 2008) www.hcch.net under "Work in Progress" and "General Affairs", p. 1.

46 Recommendations and Conclusions adopted by the Council on General Affairs and Policy of the Conference (1-3 April 2008) www.hcch.net under "Work in Progress" and "General Affairs", p. 1. 
ily matters. It approved the proposal of the Permanent Bureau that the Guide to Good Practice for Mediation in the context of the Hague Convention... be submitted for consultation to Members by the beginning of 2010 and then for approval to the Special Commission to review the practical operation of the 1980 Child Abduction Convention... at its next meeting in 2011". ${ }^{47}$

A draft Guide was circulated to the Contracting States to the $1980 \mathrm{Ha}-$ gue Convention in advance of Part I of the Sixth Meeting of the Special Commission on the practical operation of the 1980 Hague Child Abduction Convention and the 1996 Hague Child Protection Convention. The Recommendation $\mathrm{N}^{\circ} 58$ requested for revisions to the Guide in the light of the discussions of the Special Commission, also taking into account the advice of experts and to circulate a revised version to Members and Contracting States for final consultations. "A revised version of the Guide of Good Practice was circulated to the Hague Conference Members and Contracting States to the 1980 Convention in May 2012 for last comments". ${ }^{4}$

As mentioned earlier, emphasis was placed on the subject of the promotion of friendly settlements, and thus the promotion of alternative dispute resolution methods ${ }^{49}$ through mediation by means of a currently Guide to Good Practice on Mediation, ${ }^{50}$ invoking as well the usage of articles 7 and

47 Recommendations and Conclusions adopted by the Council on General Affairs and Policy of the Conference (31 March-2 April 2009) www.hcch.net under "Work in Progress" and "General Affairs", pp. 1-2.

48 Guide to Good Practice under the Hague Convention of 25 October 1980 on the Civil Aspects of International Child Abduction. Mediation. SI, 2012/16.

49 "Three forms of assisted dispute resolution are common in family matters: informal negotiations; the court process; and formal non-adversarial processes... [1] Informal negotiations... In the Convention context this is akin to the procedure in many States for seeking voluntary return or amicable resolution [with an important Authority role]... [2] court process... these negotiations are usually led by judges or lawyers and are also common in Convention cases, often leading to consent orders... [3] Formal non-adversarial processes... The most usual processes in family matters are mediation, conciliation and more recently, collaborative law". In this text mediation is only used to refer to a particular process practised by persons qualified as mediators. Vigers, S., Mediating International Child Abduction Cases. The Hague Convention, Hart Publishing, UK, 2011, pp. 11-12.

50 This Guide is the fifth Guide to Good Practice developed to support the practical operation of the 1980 Hague Child Abduction Convention. The four previously published Guides are: Guide to Good Practice under the Hague Convention of 25 October 1980 on the Civil Aspects of 
10 of the 1980 Hague Convention, ${ }^{51}$ encouraging voluntary or friendly settlements, or settlements through mediation, based upon international cooperation of authorities.

The Guide to Good Practice under the Hague Convention of 25 October 1980 on the Civil Aspects of International Child Abduction, Part V Mediation, has the next structure: $:^{52}$

- Chapter 1 offers a general overview of the advantages and the disadvantages or limits of the use of mediation in international family disputes;

- Chapter 2 explores challenges like the close co-operation, bi-lingual, bi-cultural, distance among other;

- Chapter 3 addresses the specialized training for mediation in international child abduction cases;

- Chapters 4-13 establishes the flow of the mediation process in international child abduction cases in a chronological order from questions of access to mediation to the outcome of mediation and its legal effects;

- Chapter 14 is dedicated to the use of mediation to prevent child abductions;

- Chapter 15 is dedicated other processes to bring about agreed solutionsand

- Chapter 16 refers special issues regarding the use of mediation in nonConvention cases.

International Child Abduction, Part I -Central Authority Practice (Jordan Publishing, 2003); Guide to Good Practice under the Hague Convention of 25 October 1980 on the Civil Aspects of International Child Abduction, Part II- Implementing Measures (Jordan Publishing, 2003); Guide to Good Practice under the Hague Convention of 25 October 1980 on the Civil Aspects of International Child Abduction, Part III-Preventive Measures; Guide to Good Practice under the Hague Convention of 25 October 1980 on the Civil Aspects of International Child Abduction, Part IV- Enforcement (Jordan Publishing, 2010). www.hcch.net under "Child Abduction Section" and "Guides to Good Practice".

51 We coincide with Sarah Vigers in that it is really important to make a distinction between mediation, voluntary return and amicable resolution (Article 7 Hague Convention: "Central Authorities... shall take all appropriate measures... to secure the voluntary return of the child or to bring about an amicable resolution of the issues. Article 10 Hague Convention: "The Central Authority of the State where the child is shall take or cause to be taken all appropriate measures in order to obtain the voluntary return of the child"). "The return mechanism is generally and correctly considered to be the heart of the Convention regime; however, it is neither the only nor the primary solution offered by the instrument...”, Vigers, supra n. 49, 13.

52 Guide to Good Practice under the Hague Convention of 25 October 1980 on the Civil Aspects of International Child Abduction. Mediation. SI, 2012/20. 
As we shall see, the present article does not comprehend each and every topic mentioned in said Guide to Good Practice on Mediation but it is centered around certain issues that seem noteworthy at present due to the urgent need to address them, for instance cooperation and recognition/ enforcement, conflicts of law, criminal charges, or due to the innovation implied by its implementation such as mediator training, language, cultural differences or geographical distance and the implementation and promotion of Online Dispute Resolution in those cases. ${ }^{53}$

Widely accepted doctrine converges on the need to develop the culture of agreement, a culture of peace, particularly in the field of family relations, aimed at reaching settlements after a separation, where not only a possible abduction situation is foreseen, but the establishment of related agreements needed to make pacts concerning the children without reaching the point where a judge shall decide for the parties involved.

Confronted with a balance represented by weight and counterweight systems, we have mediation which in turn offers pros and cons.

Consequently, some of the advantages of mediation are:

1) It facilitates communication between the parties "in an informal atmosphere and allows the parties to develop their own strategy regarding how to overcome the conflict". ${ }^{54}$

2) It is a structured but flexible process.

3) It can be completed more quickly than court cases, that is, less time is wasted.

4) It is consequently, less intrusive because the mediation is private, ${ }^{55}$ court is not. ${ }^{56}$

53 Latin American authors have begun to introduce these subjets, see N Rubaja, Derecho Internacional Privado de Familia. Perspectiva Desde el Ordenamiento Jurídico Argentino, Buenos Aires, Abeledo Perrot, 2012, pp. 173 and ss.

54 Guide to Good Practice under the Hague Convention of 25 October 1980 on the Civil Aspects of International Child Abduction. Mediation. SI, 2012/21.

55 We are thinking about that the mediation is confidential. The mediator holds any and all information disclosed in the mediation in confidence with a few notable exceptions: threats, child abuse and criminal activity. Overview of International Family Mediation. International Social Service-USA in collaboration with National Association for Community Mediation. www.iss-usa.org (March 25, 2013)

56 http: / /travel.state.gov/abduction/about/whatsnew/whatsnew_3859.html (march 21, 2013) Mediation. Settling out of court. However, proceedings involving children are often held behind closed doors and are reported without identifying the parties. 
5) It offers more options, that is, not only the return or not of the child, but all related agreements such as the school the child will attend, and others.

6) It empowers the parties to face future conflicts in a more constructive way.

7) It is more likely to lead to a sustainable solution ${ }^{57}$ and for this reason It is in most cases a long lasting solution.

8) It can be of assistance at an early stage of a conflict before a possible escalation;

9) It is lower cost.

10) It is cost-effective.

11) It is a mediator's best tool to help parents understand cultural differences in cases international child abduction and

12) Last but not least, it is done in the child's best interest, it can prevent unnecessary relocation of a child in return scenarios, obviously we are thinking about cases involving international parental child abduction too. ${ }^{58}$

Moreover, mediation has other advantages over litigation in international parental child abduction cases under the Hague Convention: ${ }^{59}$

1) Inconsistent and infrequent application of the treaty renders Hague litigation unpredictable, expensive and time consuming. ${ }^{60}$

57 "The range of issues the parties decide to focus on at the beginning of the mediation soon reveals that there are many more questions at stake which must at least be raised and partially — if not completely — solved during the mediation in order to find the basis for a sustainable arrangement... In other words, the procedure is not limited to the issues under legal dispute, but rather open to a much wider range of topics the participants need to settle". C Paul, “An International Mediation: From Child Abduction to Property Distribution”, (2009) 3 American Journal of Family Law, 167.

58 http://travel.state.gov/abduction/about/whatsnew/whatsnew_3859.html (March 21, 2013) Mediation. Settling out of court.

59 Zawid, supra n. 17, pp. 19-29.

60 For example, in the United States each international child abduction case must be decided by applying the Hague Convention, ICARA, conflicts of law, federal statutes, and a growing list of federal cases that have interpreted the Convention and ICARA.; and the 
2) Mediation has more options (particularly Hague return cases), that is, once an agreement is reached about where the child will reside, parents can agree to custodial details that would be outside the perview of a court under the Hague Convention. ${ }^{61}$

3) Hague cases can lead to a wide range of criminal, civil, and economic penalties that could be avoided or cured by mediation ${ }^{62}$ and

4) Mediation allows the parties to address a broader range of issues than Hague litigation would. ${ }^{63}$

Notwithstanding the aforementioned advantages, not all family conflicts can be solved amicably. Some limitations, disadvantages or drawbacks of mediation are: ${ }^{64}$

\section{1) The nature of the conflict;}

cost of specialists is prohibitive. The mediation can facilitate an expeditious resolution, bring about balance of power and reduce costs. Ibidem, pp. 22-23.

61 http: / / travel.state.gov/abduction/about/whatsnew/whatsnew_3859.html (March 21, 2013) Mediation. Settling out of court.

62 The taking parent can be subject to a wide range of civil, criminal, a financial penalties by the left-behind parent and penalties can extend to thirds parties like grandparents or family lawyers that were "co-conspirators". "In the U.S., potential claims include civil conspiracy or even charges under the Racketeer Influenced and Corrupt Organizations Act (RICO). Abducting parents can also face potentially devastating immigration consequences". Zawid, supra n. 17, 29. About the issue of compensation for the left-behind parent see R Schuz, "How to Compensate the Left-Behind Parent in International Child”, (2012) 23 Columbia Journal of Gender and Law, 65-131. Both the left-behind parent as well as the taking parent could benefit from mediation. Schuz, Shmueli, "Between Tort Law, Contract Law and Child Law: How to Compensate the Left-Behind Parent in International Child”, Columbia Journal of Gender and Law, USA, 23, 2012, pp. 65-131.

63 "Mediation is also promising in cases where the abducting parent takes the child back to his or her country of origin... because of 'feelings of isolation' in the child's state of habitual residence. Isolation stems from such factors as a lack of family support, language and cultural barriers, or just general homesickness. In a number of these cases, the abducting parent does not necessarily want to relocate permanently or cut off the child from contact with the leftbehind parent". The mediation process can bring about many positive deals related to visit, travels, support, education, etc. Zawid, supra n 18, 26. In the same sense see C Paul, "Family Mediation in International Child Custody Conflicts: The Role of the Consulting Attorneys", (2008) 22 American Journal of Family Law, 42.

64 Guide to Good Practice under the Hague Convention of 25 October 1980 on the Civil Aspects of International Child Abduction. Mediation. SI, 2012/23. 
2) The specific needs of the parties;

3) The specific circumstances of the case;

4) The inability or unwillingness to meet or listen;

5) The particular legal requirements;

6) The use of mediation as a delaying tactic in Hague return $\operatorname{cases}^{65}$ and

7) The fact that agreements must be recognized by a court or incorporated into a court order to be legally binding, a topic of paramount importance covered in the section regarding cooperation.

With this overview, it is clear that the benefits of mediation in cases of international child abduction are extraordinary; the advantages far outweigh the disadvantages, the point being, that it needs to be conducted in an ethical manner for it to be an appropriate and effective tool to resolve cases of international child abduction. Several goals need to be pursued:

1) To safeguard the best interest of child;

2) To safeguard the integrity of a mediation process and

3) To safeguard the commitment acquired towards the international community through international organisms like The Hague Conference of Private International Law.

A Guide to govern mediations in this field, is likely to become a good way to resolve most problems. Mediation is gaining ground and new resources are becoming available all the time.

\section{INTERNATIONAL FAMILY MEDIATION: Challenges AND SPECIALIZED NECESSITY}

When we think about challenges, especially those related to mediating an international parental abduction case, we need to think that these cases involve much more than knowing some family law, that is, these entail, for

65 For these reason, in the United States, if a child has been abducted to a country that is a Hague Abductions Convention partner, it is necessary to ask an attorney whether you should proceed with a Hague return application at the same time try mediation. 
instance, complex emotions, strict time constraints, multiple nations' laws and policies, intricate international conventions, government officials, interpreters, lawyers, judges, parents and children and all, in most cases physically — and/or emotionally_ located thousands of miles apart. ${ }^{66}$

In a domestic mediation process, trained professionals, who often have legal or social work backgrounds, work with both parents to reach a solution to the controversy. The mediator or mediators help both parents to feel comfortable with the solution. ${ }^{67}$ Mediation for international cases needs something more because there are distance, language and cultural barriers and different legal systems that may complicate a resolution; perhaps the most important point to acknowledge is that the mediator must be highly skilled and trained, moreover, she or he has to be familiar with a variety of international child custody and abduction laws. ${ }^{68}$ When a solution is reached, the parents typically sign a written mediation agreement; once filed in a court, this is a public document and can be used in court if the agreement is ever violated, ${ }^{69}$ on other occasions a final agreement,

66 Kucinski, M. A., "Culture in International Parental Kidnapping Mediation”, (2009) 9 Pepperdine Dispute Resolution Law Journal, University School of Law, 556.

67 Overview of International Family Mediation. International Social Service-USA in collaboration with National Association for Community Mediation. www.iss-usa.org (March 25, 2013)

68 Hatfield, H. N., "Growth Spurt Hits International Law Related to Children”, (2012) Maryland Bar Journal, 44.

We emphasize the convenience of the Guidelines implementation at country or even state level (within a federal system), in the hopes of harmonizing criteria about the topic of interest, international family mediation, thus providing certainty and judicial security to international parental child abduction cases linked to international family mediation. The contents for these Guidelines should encompass issues such as mediator training (fields and hours or techniques, for instance), domestic violence and mediation, mediation principles, online dispute resolution and mediation, cost, among others. See in the United States, "Guidelines for Mediating International Family Matters", Task Force on International Family Mediation, ABA/SIL, 12 February 2013.

In connection with ODR implementation through instruments such as these Guidelines see also, S. Jani, Mediating from a Distance: Suggested Practice Guidelines for Family Mediators (British Columbia Mediator Roster Society, 2010), available at: http: / /www.mediatebc.com / PDFs / 1 14-Family-Mediation---FAQs/Mediating_From_a_Distance_2nd_Edition_Nov-2012.aspx.

69 "The parties choose how they want the agreement implemented. Agreements can be formal and filed with the courts or they can be more informal and used as a guide for their future behavior. Parties can ask that the court or their lawyer to fashion the agreement into an 
through mediation, that agreement may or may not be legally enforceable in both countries.

Many of these challenges are dealt with in the mentioned Guide of Good Practice and will be the object of study in this article.

\section{Challenges of Private International Law}

\section{A. Cooperation between Authorities}

When the Hague Conference debated the problem of international parental child abduction, the conclusion was that a convention on cooperation would be more effective than a traditional private international law treaty focused on harmonizing the rules for jurisdiction, recognition, and enforcement of custody judgments. ${ }^{70}$

As it developed the Children's Conventions, the Hague Conference transformed itself and international family law. Cooperation based upon the most recent conventions entails the appointment of Central Authorities in contracting states and the communication between the diverse interlocutors involved in a specific subject.

As we see, cooperation is a fundamental principle that needs to be upheld (in every field) but cooperation between Central Authorities under the 1980 Hague Convention is also a goal, because this convention urges states party to cooperate and to employ a comprehensive range of remedies and resources to resolve international parental kidnapping disputes expeditiously. ${ }^{71}$

order to be signed by the court". Overview of International Family Mediation. International Social Service-USA in collaboration with National Association for Community Mediation. www.iss-usa.org (March 25, 2013).

70 Pérez Vera, supra n. 26, 426, 435.

71 Article 7, The 1980 Hague Convention. Central Authorities shall co-operate with each other and promote co-operation amongst the competent authorities in their respective State to secure the prompt return of children and to achieve the other objects of this Convention; they shall take all appropriate measures a) to discover the whereabouts of a child who has been wrongfully removed or retained; b) to prevent further harm to the child or prejudice to interested parties by taking or causing to be taken provisional measures... f) to initiate or facilitate the institution of judicial or administrative proceedings with a view to obtaining the return of the child and, in a proper case, to make arrangements for organizing or securing the effective exercise of rights of access... 
Under the Hague Convention, Central Authorities are empowered as the administrative and representative organ of the signatory states whose function and placement — within the national government — may vary but their role is that of an active facilitator ${ }^{72}$ or cooperative and collaborative entity. ${ }^{73}$

When arranging for contact between the left-behind parent and abducted child in the course of the mediation process, co-operation with the authorities may be necessary to eliminate any risks for the child, including re-abduction. ${ }^{74}$

Central Authorities are encouraged "to take a pro-active and hands-on approach in carrying out their respective functions in international access... contact cases". ${ }^{75}$ Mediators should be aware of the considerable assistance that Central Authorities may be able to provide in arranging for interim contact between the left-behind parent and the abducted child. They should equally be aware of the need for close co-operation with Central Authorities and other bodies regarding the arrangement of necessary protective measures. ${ }^{76}$

When an agreement between parents has been reached through mediation and these results are achieved, it should also be consistent with the spirit of the 1980 Hague Convention itself, which establishes in article 7 that:

Central Authorities shall co-operate with each other and promote co-operation amongst the competent authorities in their respective State to secure the prompt return of children and to achieve the other objects of this Convention; they shall take all appropriate measures... c) to secure the voluntary return of the child or to

72 Pawlowski, R., "Alternative Dispute Resolution for Hague Convention Child Custody Disputes”, (2007) 45 Family Court Review, 305.

73 Guide to Good Practice for the use of Central Authorities. http: / /www.hcch.e-vision.nl/ upload/abdguide_e.pdf.

74 Guide to Good Practice under the Hague Convention of 25 October 1980 on the Civil Aspects of International Child Abduction. Mediation. SI, 2012/72.

75 Conclusions \& Recommendations $\mathrm{N}^{\circ} 18$ of Part I of the Sixth Meeting of the Special Commission and Guide to Good Practice on Transfrontier Contact Concerning Children, Jordan Publishing, 2008, http: / / www.hcch.net under "Child Abduction Section" then "Guides to Good Practice".

76 Guide to Good Practice under the Hague Convention of 25 October 1980 on the Civil Aspects of International Child Abduction. Mediation. SI, 2012/72. 
bring about an amicable resolution of the issues, d) to exchange, where desirable, information relating to the social background of the child; e) to provide information of a general character as to the law of their State in connection with the application of the Convention; $f$ ) to initiate or facilitate the institution of judicial or administrative proceedings with a view to obtaining the return of the child and, in a proper case, to make arrangements for organizing or securing the effective exercise of rights of access; $g$ ) where the circumstances so require, to provide or facilitate the provision of legal aid and advice, including the participation of legal counsel and advisers; $h$ ) to provide such administrative arrangements as may be necessary and appropriate to secure the safe return of the child; i) to keep each other informed with respect to the operation of this Convention and, as far as possible, to eliminate any obstacles to its application.

That is, it is assumed that Central Authorities should collaborate with each other and that they should promote cooperation among competent Authorities within their respective states, seeking to guarantee the immediate return of the children, as well as to accomplish all other objectives of the Convention. In particular, they must adopt either directly or through an intermediary, all conductive measures that lead to guaranteeing the voluntary return of the child or to facilitate an amicable resolution.

Finally, it should be noted that when a treaty is signed, Central Authorities are designated and, normally, such authorities are located within the Foreign Affairs Secretariats or Ministries of each State. Concerning such designation and location, the sixth meeting of the special commission for the practical application of the Hague 1980 convention, established in its recommendations and conclusions, the possibility that through such authorities:

61. The Special Commission notes the efforts already being made in certain States to establish a Central Contact Point in accordance with the Principles. States are encouraged to consider the establishment of such a Central Contact Point or the designation of their Central Authority as a Central Contact Point. The contact details of Central Contact Points are available on the Hague Conference website. ${ }^{77}$

77 Conclusions and Recommendations of the Sixth Meeting of the Special Commission (Part I - June 2011) www.hcch.net under Child Abduction Section. 
The establishment of such Central Points of Contact is in principle a laudable initiative that is welcome as well, ${ }^{78}$ nonetheless, we point out that there is a possibility that this becomes a complex issue when it comes to verifying that the international mediator list posted, contains only those that are duly trained and not just those who gained access to such lists.

We would not like to conclude this section dedicated to cooperation without previously highlighting one of the most critical and controversial topics nowadays, that is directly related to the cooperation contents of the 1980 Hague Convention. Co-operation among administrative/judicial authorities may be needed to help facilitate the enforceability of the agreement in all the States concerned. One of the proposals, as part of the Conclusions and Recommendations of Part II (January 2012) of the Sixth Meeting of the Special Commission to review the practical operation of the 1980 Hague Convention and the 1996 Hague Convention, recommended that further substantive work be done in the specific area "cross-border recognition and enforcement of agreements in international child disputes, possibly in the form of a binding instrument and not tied specifically to the 1980 or 1996 Conventions". ${ }^{79}$ In this sense, The Hague Conference on Private International Law through its governing Council on General Affairs and Policy, in recognition of the growing use of mediation and other forms of amicable resolution to resolve international child disputes, mandated that an Experts' Group be established "to carry out further exploratory research on cross-border recognition and enforcement of agreements reached in the course of international child disputes...”. This Experts' Group must examine and identify the nature and extent of the legal and practical problems, including jurisdictional issues, involving the cross-border recognition and

78 Conclusions and recommendations adopted by the Council on General Affairs and Policy of the Conference (9-11 April 2013), Hague Conference on Private International Law, n 23, expresses that “... The Council welcomed the increased engagement an activity by the members of the Working Party and agreed that the working Party continue its work on the implementation of mediation structures and establishment of Central Contact Points, with the expectation of a further report on progress to the Council in 2014", www. hcch.net under Child Abduction Section. See also www.hcch.net under Child Abduction Section, Cross-border family mediation, for the moment only six countries have Central Contact Points.

79 "Report of the Further Work Recommended by the Special Commission on the Practical Operation of the 1980 Child Abduction Convention and the 1996 Child Protection Convention”, Prel. Doc. No 12, March 2012, p. 4. www.hcch.net. 
enforcement of these voluntary agreements and to evaluate the benefit of a new instrument, whether binding or non-binding, in this area. Definitely, the goal of the meeting will be to prepare conclusions and recommendations for the Council evaluating the need, desirability, and feasibility of a future instrument. ${ }^{80}$

\section{B. Conflicts of Law}

The globalization and mobile population call for a good regulation of family law. All countries face a challenge when confronted with a situation involving Private International Law. For instance, the United States family law has traditionally been a subject of local or state concern, generating significant conflict of laws problems at even national level. Ann Laquer Estin has expressed that in the United States "National and local laws are inadequate to manage transnational family issues, especially in cases of international adoption or parental abduction... closely related to a number of laws of different hierarchy" ${ }^{11}$ even in the United States, participation in multilateral treaty regimes has been a source of political and legal controversy, often framed in terms of federalism. ${ }^{82}$ The 1980 Hague Convention is implemented into U.S. law through the International Child Abduction Remedies Act (ICARA). ${ }^{83}$

In this way, "The United States have no national federal family law, but it consists of the laws of each individual state, which lack consistency. There is a Uniform Law Commission [a non-profit organization based in the United

80 Report of the Further Work Recommended by the Special Commission on the Practical Operation of the 1980 Child Abduction Convention and the 1996 Child Protection Convention”, Prel. Doc. No 12, March 2012, www.hcch.net at paras 11-37; 44.

81 Its implementing legislation in the U.S. is the International Child Abduction Remedies Act (ICARA), 42 U.S.C.\&\&11601-11610 (1988). As an international treaty, the Hague Convention is on a par with the Constitution and supersedes any conflicting laws. AL Estin, "Families Across Borders: The Hague Children's Conventions and the Case for International Family Law in the United States", 62 Florida Law Review, 2010, pp. 71-ss.

82 "In constitutional terms, Article II, Section 2, assigns to the President and the Senate responsibility for conducting foreign affairs and determining the nation's obligations under international law". Estin, supra n 80, 101. About the interaction between state and federal laws in American Family Law, see AL Estin, "Sharing Governance: Family Law in Congress and the States”, 18 Cornell J.L. \& Pub., 2009, 267.

8342 USC 11601 et seq. 
States that drafts uniform laws in various fields, including family law $\left.{ }^{84}\right]$ in a effort to create some cohesive understanding among the states, but this process only works if each state adopts the uniform law in substantially the form in which it was drafted. There is also little consistency among each state's selection, credentialing, and standards for mediators. Each state defines mediation, when it may be used, and who may mediate. Some states do not define any of these criteria, leaving mediation an un-regulated, ad hoc profession...”. ${ }^{85}$ Notwithstanding this situation the American Bar Association's Section of International Law has formed a task force to make recommendations in this regard, including minimum mediator credentials, a training curriculum for mediators, and how to handle allegations of domestic violence in these cases. ${ }^{86}$

This is how the internationalization of laws affects domestic laws and one such area of consequential change is the development of new primary sources of domestic law within the United States, such as the Uniform Child Abduction Prevention Act (currently in force in the District of Columbia $^{87}$ ) and federal criminal statutes. "In the common law domain, tortu-

84 www. uniformlaws.org. To stress the very relevant role played by the Uniform Law Commission, as a U.S. nonprofit organization that harmonizes the states'laws, stemming from the fact that the U.S. has signed the 1996 Hague Convention, works in the implementation, for instance, of the draft regarding Uniform Child Custody Jurisdiction \& Enforcement Act (UCCJEA). Under these UCCJEA In the US agreements reached through mediation may be submitted to a state court in the form of a stipulated, agreement which can be recognized and enforced in that jurisdiction as well as within other US States. S. Vigers, Note on the development of mediation, conciliation and similar means to facilitate agreed solutions in transfrontier family disputes concerning children especially in the context of the Hague Convention of 1980, Doc. Prel. No 5, www.hcch.net.

85 Kucinsky, supra n. 21, 83. Take into consideration that the requirement of both states should be met.

86 Hatfield, supra n. 68, 44 and see "Guidelines for Mediating International Family Matters", 12 February, 2013.

87 District of Columbia Code, annoted, \&16-4606 et. Seq. "UCAPA is particularly useful in helping prevent parental child abductions because it list a fairly exhaustive set of factors designed to alert a judge to the possibilities of child abduction...: abandoning employment, selling a primary residence, closing bank accounts or seeking passports for themselves or the child. Other risk factors include: a person who has strong familial or cultural ties to another country or state, or who has used multiple names or identities. One often overlooked risk factor is the likelihood a parent could take a child to a country that is not a signatory of the 1980 Abduction Convention”. We coincide and we put special emphasis or stress that the United States no border exit controls, that is, "no requirement exists that a parent must demonstrate 
ous interference with parental rights is an old concept finding new life in reaction to the globalization of families and the limited application of the 1980 Abduction Convention". 88

Issues of jurisdiction and applicable law need to be taken into consideration when drawing up the mediated agreement. ${ }^{89}$

In this sense, the judicial and administrative authorities of the requested State and the requesting State should co-operate with each other as much as possible to overcome possible difficulties in rendering an agreement that amicably settles an international child abduction dispute, that is legally binding and enforceable in both States. ${ }^{90}$

When confronted with an international parental child abduction, the children, the most vulnerable family members, are subjected to situations that appear to make them more vulnerable still, because the parties face multifaceted challenges in two or more legal systems, thereby exposing the child to an even more complicated and protracted adjudication and posttrial enforcement..$^{91}$ Time, in those cases involving early stages of human development, has a special value..$^{92}$

Finally, the 1980 Hague Convention has perfectly defined competencies by establishing that it will be the judge of the place where the minor has been wrongfully brought to or wrongfully withheld, the one to decide on restitution as well as which judge will resolve on guard and custody issues, that is, the judge in the habitual residence of the minor prior to the removal or wrongful retention and thereby, the applicable law will be determined by the judge resolving on either matter; yet the true challenge lies on clarifying the hierarchy of the international norms applicable in each of the countries involved, as we have expressed in our exposition of the United States case.

permission to take a child out of the United States before leaving”. Hatfield, supra n. 66, 43. "The existence of «exit» controls varies from country to country". Kucinsky, M. A., supra n. 21,84 .

88 Hatfield, supra n. 68, 42.

89 Guide to Good Practice under the Hague Convention of 25 October 1980 on the Civil Aspects of International Child Abduction. Mediation. SI, 2012/83.

90 Idem.

91 Pawlowski, supra n. 72, 302.

92 Idem. 


\section{Immigration Issues}

In cases of international family disputes, visa and immigration issues often add to the difficulties of the case. In order to promote amicable resolutions of international family disputes, States should take measures to ensure that a left-behind parent is capable of obtaining necessary travel documents to attend a mediation session in the country to which the child was abducted, or indeed to participate in legal proceedings. ${ }^{93}$

The 1980 Hague Convention focuses on issues of residency, not citizenship. The Convention does not confer any immigration benefit. Anyone seeking to enter, for instance, the United States who is not a United States citizen must fulfill the appropriate entry requirements, even if that person was ordered by a court to return to the United States. This applies to children and parents involved in any child abduction case, including a Hague Abduction Convention case. ${ }^{94}$

The provision of travel documents may also play an important part in the result of legal proceedings or mediation in an international parental dispute, in cases where the return of a child is ordered in Hague return proceedings, the taking parent might need travel documents to re-enter the State of the child's habitual residence together with the child. States should facilitate the provision of necessary travel documents in such cases. The same applies to cases where the taking parent decides to return the child voluntarily, including here a return of the child and parent has been agreed on in mediation. Nor should visa and immigration issues constitute an obstacle for the cross-border exercise of contact rights; the right of children to have contact with both of their parents, as supported by the UNCRC, needs to be safeguarded in the best interest of the child..$^{95}$

In the specific case of the United States of America, when a taking parent in a Hague Abduction Convention case is ineligible to enter the United States under United States immigration laws, the parent may be paroled for a limited time into the United States through the use of a Significant Public

93 Guide to Good Practice under the Hague Convention of 25 October 1980 on the Civil Aspects of International Child Abduction. Mediation. SI, 2012/33.

94 http: / / travel.state.gov/abduction/about/whatsnew/whatsnew_3859.html (March 26, 2013) under "Possible Solutions-Using the Hague Abduction Convention".

95 Guide to Good Practice under the Hague Convention of 25 October 1980 on the Civil Aspects of International Child Abduction. Mediation. SI, 2012/34. 
Benefit Parole in order to participate in custody or other related proceedings in a United States court. ${ }^{96}$

\section{Criminal Charges}

The Hague Convention on the Civil Aspects of International Child Abduction is designed to enable the crisis to be resolved by mandating that the authorities in the state to which the child has been abducted, order return of the child to the state of his habitual residence immediately preceding the abduction, unless one of the narrow exceptions in the Convention is established.

Although the 1980 Hague Child Abduction Convention only deals with the civil aspects of international child abduction, criminal proceedings against the taking parent in the country of the child's habitual residence may affect return proceedings under the Hague 1980 Convention. ${ }^{97}$ As such, criminal charges may have an unintended negative effect on the operation of the Convention. " "With the Convention, the emphasis is on the swift return of a child to his or her place of habitual residence where the custody dispute should be resolved. Courts in some countries, including the United States,

96 http: / /travel.state.gov/abduction/about/whatsnew/whatsnew_3859.html (March 26, 2013) under "Possible Solutions-Using the Hague Abduction Convention".

97 Guide to Good Practice under the Hague Convention of 25 October 1980 on the Civil Aspects of International Child Abduction. Mediation. SI, 2012/34.

98 A case, on this occassion with significant media coverage, was the "Carrascosa case". María José Carrascosa, a Spanish citizen, is imprisoned in New Jersey, since november 2006 for taking to Spain, in January 2005, her daughter Victoria, whose father was Meter Innes, an American citizen. Imprisoned in November 2006 and sentenced to 14 years for his daughter's wrongful removal. On april 20 2009, American and Spanish judges met to try to reach an agreement but it was not possible. In april 2013 María José Carrascosa filed a new habeas corpus appeal to the New Jersey federal court. The facts: The couple resided in the U.S. during the five years that the relation lasted. In January 2005 Victoria travelled to Spain along with her mother Maria Jose. Meter filed a request for international return of the minor and a court in Valencia, Spain, denied the return of the child on July 62005 considering there was no wrongful child removal, nonetheless the Supreme Court of New Jersey, ruled 5 months earlier that the child should be returned, and since the mother did not, she ended up in prison the moment she travelled to the U.S. Pere Ríos, "Exteriores tramita 84 casos de sustracción internacional de hijos", El País, Barcelona, 13 de abril de 2009, www.elpais.com/articulo /sociedad / Exteriores/tramita/84/casos/sustracción/internacional/hijos/elpepisoc/20090413elpepisoc_2/tes (accessed 13 de abril de 2009). 
have denied return of children solely because the taking parent would be arrested if he accompanied the child home". ${ }^{99}$

It is worth noting that the United States Department of State, Office of Children's Issues functioning as Central Authority, when it opens an international parental child abduction case, it expresses that it should be done directly at the office of children's issues or the National Crime Information Center (NCIC) but advices that "It is not always a good idea to file criminal charges against the abducting parent at this time [we understand on the opening]" ${ }^{100}$ because once filed, criminal charges may be difficult or impossible to remove. ${ }^{101}$

These cases involving international child parental abduction, always have high conflict and here are three aspects to consider in cases with criminal charges: the position of the left-behind parent; the position of the taking parent and the position about the abducted child.

The left-behind parent wants to stay in the position he or she was before the abduction, economically, emotionally and psychologically. ${ }^{102}$ In the economy aspect when confronted with an unfamiliar legal, cultural, and linguistic atmosphere, for instance, he might incur costs in identifying the whereabouts of the child, in travelling ${ }^{103}$ to and staying in the state of abduction, in paying legal costs of submitting an application for the child's return in the courts of the requested state. In the emotional aspect, the

99 http: / / travel.state.gov/abduction/about/whatsnew/whatsnew_3859.html (March 26, 2013) under "Possible Solutions-Using the Hague Abduction Convention".

100 http: / / travel.state.gov/abduction/about/whatsnew/whatsnew_3859.html (March 21,2013) under Mediation.

101 http: / / travel.state.gov/abduction/about/whatsnew/whatsnew_3859.html (March 26, 2013) under "Possible Solutions-Pressing Criminal Charges". "International parental child abduction is crime in every State [the United States] and the District of Columbia... International parental child abduction may also a Federal crime under the International Parental Kidnapping Crime Act (IPKCA)".

102 "In many of these cases, the central issue for the left-behind parent is, in fact, contact or visitation, and not necessarily the wish for a permanent return". Hutchinson, A. N., "Child Abduction Mediation Pilot Project”, IFL, September, 2001, p. 151.

103 In the United States, the Department of Justice's Office for Victims of Crime (OVC) has established a fund called The Federal Crime Victim Assistance Fund. When no other resources are available, this fund has at times been used to assist left-behind parents with travel costs associated with reunification. The National Center for Missing and Exploited Children (NCMEC) administers the OVC funds for left-behind parents. http://travel.state.gov/abduction/about/ whatsnew/whatsnew_3859.html (March 26, 2013) under "Reuniting with your Child". 
uncertainty to recover the child and the lack of or reduced contact with the child cause considerable emotional distress, without mention when domestic-violence allegations are made against them. ${ }^{104}$

A number of questions arise. What is the appropriate way to require the abductor or taking parent to compensate the left-behind parent? Through a civil tort claim against the taking parent? ${ }^{105}$ Through a civil contract claim against the taking parent when a contract between the parents has been breached? Through a criminal proceeding against the taking parent ${ }^{106}$ Or by the court of the state which is requested to return the child, as part of the proceedings under the Hague Convention?

To Schuz and Shmueli the issue of compensation for the left-behind parent is necessary and they conclude that the abduction convention model is the preferred model or solution for the left-behind parent ${ }^{107}$ in spite of the dilemmas this might entail.

Mediation in international child abduction cases needs to take into consideration possible criminal proceedings initiated against the taking parent in the country from which the child was abducted. Where criminal proceedings were initiated, the issue needs to be addressed in mediation. Close co-operation among the relevant judicial and administrative authorities may be needed to help ensure any agreement reached in mediation is not frustrated by ongoing criminal proceedings. ${ }^{108}$

104 Browne, N. L., "Relevance and Fairness: Protecting the Rights of Domestic-Violence Victims and Left-Behind Fathers under the Hague Convention on International Child" (2011) Duke Law Journal, 1214.

105 In Maryland, the case Khalifa v. Shannon, 404 Md. 107, discussed a tort cause of action in a parental child abduction. Maybe it is an interesting option to seek financial compensation in court from a person to right a wrong when there is no other way to right that wrong, however, in the Khalifa case, the father was granted a large sum but could never benefit from it because the mother is living in Egypt where the U.S. court sentence has no effect, therefore, unless the is some way to execute the sentence at the moment it is issued, this type of relief is only deterrent. Conversation with Melissa A. Kucinski.

106 In the U.S., only the State's Attorney/District Attorney can decide what charges will or will not be dropped, despite the best intentions of the parent who originally made the complaint and this may be a difficulty for the mediation. Conversation with Melissa A. Kucinski.

107 Schuz, R., "Between Tort Law, Contract Law and Child Law:How to Compensate the Left-Behind Parent in International Child”, (2012) 23 Columbia Journal of Gender and Law, 65-131.

108 Guide to Good Practice under the Hague Convention of 25 October 1980 on the Civil Aspects of International Child Abduction. Mediation. SI, 2012/34. 
Another issue, is that for the left-behind parents seeking the return of their children, courts in many countries do not take into account the prior decisions made by courts in their country of habitual residence. ${ }^{109}$ To us, the recognition and the enforcement of these orders, particularly between Convention's States Parties, must be binding because the majority of the international conventions have regulated these situations. For instance the 1980 Hague Convention has in place a cooperation system between Central Authorities in articles 16 and 17, mentioned earlier.

On the other hand, the taking parent has another problem to solve, we refer to the immigration situation and the potentially devastating immigration consequences which have already been addressed in the previous paragraph, apart from those linked to criminal lawsuits filed by the affected parent which lead only to further complications and to hinder voluntary returns or a return ordered by a tribunal of the state where the child is being withheld wrongfully as we have previously shown from a North American context.

And last but not least; on one hand, the consequences for an abducted child are incommensurable. "Children who are abducted by their parents are often taken from their familiar environment and suddenly isolated from their extended families, friends, and classmates. In an effort to evade law enforcement, the taking parents may relocate them frequently and/or take them out of school unexpectedly". ${ }^{110}$ An abducted child is at risk of serious emotional and psychological problems with long-term consequences even if the child is reunited with the left-behind parent; It may happen that they do not have a language in common or maybe her/his left-behind parent has remarried and the child has a new family. ${ }^{111}$

On the other hand, "Depending on the circumstances, criminal charges can be a powerful tool to achieve [the] child's safe return; however, they

109 Arguing the sovereign nation because "sovereign nations cannot interfere with each other's legal systems, judiciaries, or law enforcement" or "generally every country only has jurisdiction within its own territory and over people present within its borders" or "court orders are not generally recognized in other countries". http: / / travel.state.gov/abduction / about / whatsnew/whatsnew_3859.html (march 21, 2013) "Possible Solutions-Using the Hague Abduction Convention”.

110 http://travel.state.gov/abduction/about/whatsnew/whatsnew_3859.html (March 26, 2013) under "Solutions" The Human and Social Cost of International Parental Child Abduction.

111 In this sense, see the section regarding the Childs's right to being listened. 
can also have the opposite effect and jeopardize the return of [the] child”. ${ }^{112}$ Is filing criminal charges an effective option? ${ }^{113}$ As in previous parts of this text, pros and cons are highlighted in order to visualize what the final balance is. Thus, the advantages in these situations are:

- The criminal process may help to locate the child;

- Prosecutions may protect children from repeated abductions and

- A public awareness of successful prosecution of an abductor may help deter others abductions;

The disadvantages are: ${ }^{114}$

- An outstanding criminal warrant may deter a voluntary or negotiated return;

- Some foreign judges have refused to order a child's return under the Convention if the parent's return would likely result in his or her arrest;

112 http://travel.state.gov/abduction/about/whatsnew/whatsnew_3859.html (March 26, 2013) under "Possible Solutions-Using the Hague Abduction Convention".

113 In the Carrascosa case, commented above, the child is with neither the father nor the mother because the sentence is against the return of the child to the father and the mother is serving a sentence for contempt of court and international child abduction.

114 We shall not state it explicitly, but among the disadvantages one may count parental allienation The topic of parental allienation needs to be addressed in cases of international parental child abduction. González Martín, supra n 6. Violence and parental alienation are relatively frequent in cases of separation or divorce. Dissociated families where the spouses no longer live together. The parental alienation syndrome (PAS) is one of the most common practices that can be found when facing marriage breakdown when there are children. The concept born with Richard Gardner, see RA Gardner, Recent Trends in Divorce and Custody Litigation, Academy Forum, 1985. The form of the breakdown and its collateral damages inflicted upon the children can had incommensurable dimensions, where the stance of the parents regarding the conflict of interests prevails over other problems that should in principle be regarded as more relevant the classic or traditional focus on losses and gains is a conflict generating scenario unfavorable for peaceful solutions. In the international context there are no laws aimed uniquely at parental alienation, but its effects can be mitigated through the enforcement of certain international instruments, that can be applied universally or regionally, when dealing with the international abduction of a girl, boy or teenager by one the parents - where parental alienation occurs almost systematically — one should consider or visualize working in the implementation of / of standing for extrajudicial conflict resolution. 
- The taking parent may react by increasing the efforts to remain undetected;

- It can be emotionally damaging on the child, the child has substantial long-term consequences. ${ }^{115}$

\section{Specialization and Formation of International Mediators}

There are many aspects to take into consideration when analyzing what the training of an international family mediator should be; nevertheless, on this occasion due to the scope of the present article, we shall focus on specific issues related to international parental child abduction and mediation.

That way, general and particular characteristics of mediation and mediators such as culture, domestic violence or geographical distance and communication technologies, will be addressed in a cross-border context. Such aspects are largely the object of study of a Soft Law instrument such as the Guide for Good Practice on Mediation that is commented in the present article.

\section{A. International Family Mediator}

Mediation advantages/disadvantages and limitations were discussed earlier. All of these issues are closely correlated to mediator training.

Hence the need to emphasize the importance of the mediator's role. First: "A [good] mediator helps two parties communicate effectively to reach a mutually acceptable solution to a dispute". ${ }^{116}$ Second: "A family mediator is skilled in managing complex emotional issues internalized in parents debating the present and future of their child." ${ }_{117}$ Third: "A [n international] family mediator working with parents in cross-border custody disputes must additionally account for the physical separation between parent and child". ${ }^{118}$ Specifically, in this context, we can see two things: an

115 Among others: http://travel.state.gov/abduction/about/whatsnew/whatsnew_3859.html (March 26, 2013) under "Possible Solutions-Using the Hague Abduction Convention".

116 Kucinski, M. A., "The Pitfalls and Possibilities of Using Technology in Mediating CrossBorder Child Custody Cases”, (2010) Journal of Dispute Resolution, 297.

117 Idem.

118 Idem. 
Alternative Dispute Resolution (ADR) like an international family mediation $^{119}$ and an Online Dispute Resolution (ODR); ${ }^{120}$ both could be good - or even the best — options. ${ }^{121}$ We cannot forget that the technology is all around us. Kucinski has expressed that "Technology is allowing people to have a voice, to be heard, and will no doubt be an increasingly important tool for mediators in cross-border disputes". ${ }^{122}$

Because of all those features or situations, a case of international child abduction - a complicated legal issue, as well as an urgent and in most cases hostile situation - requires, in the best interest of the child, to be solved by a good mediation process, where there are two parents who elect to cooperatively resolve issues related to their child without court intervention. ${ }^{123}$

Among the many situations that exemplify the usefulness of mediation in international family disputes through a specialized mediator, we have: ${ }^{124}$

- at a very early stage in a family dispute concerning children, mediation can be of assistance in preventing abduction;

- in the context of international child abduction, mediation between the leftbehind parent and the taking parent may facilitate the voluntary return of the child or some other agreed outcome;

- in the course of Hague return proceedings, mediation may be used to establish a less conflictive framework and make it easier to facilitate contact between the left-behind parent and the child during the proceedings.

119 González Martín, N., "Apuntes sobre la mediación como medio alternativo de solución de conflictos: el contexto español y mexicano", Derecho internacional privado — derecho de la libertad y el respeto mutuo-. Ensayos a la memoria de Tatiana B. de Maekelt, Asunción, CEDEPASADIP, 2010, pp. 615-646.

120 Albornoz, M. M. and González Martín, N., "Feasibility Analysis of Online Dispute Resolution in Developing Countries", n. 44 The University of Miami Inter-American Law Review, 2013.

121 "Many mediators prefer to mediate a dispute face-to-face, however, that is often times impossible. One parent may be unable to travel for practical (i.e. the cost) or logistical (i.e. unable to obtain a visa) reasons. Therefore, some mediators may have no choice but to use technology to facilitate mediation between parents”. Kucinski, supra n. 116, 298.

122 Kucinski, supra n. 116, 297.

123 Idem.

124 Guide to Good Practice under the Hague Convention of 25 October 1980 on the Civil Aspects of International Child Abduction. Mediation. SI, 2012/20. 
- in a return order, mediation between the parents may assist in facilitating the speedy and safe return of the child, among others.

On the other hand, it can be shown that whenever international family mediation takes place, culture is generally present. These multi-cultural mediations require training in the mediation process itself, family issues, international laws, and a firm grasp of how to use culture instead of allowing it to be a hindrance.

One of the most important goals for the mediator is to find the correct balance to motivate two differently cultured individuals towards reaching a common goal. To this end, in cases of international parental abduction, the mediator needs to prepare for the mediation with a knowledge of potential obstacles to good communication and potential obstacles that may impede the mediator's ability to work with the parents. The idea is to have a focus on relationship-building.

Mediators in cases of cross-cultural parental abduction need to be trained to deal with emotions and, in this context, to accommodate emotionally expressive behavior in order to effectuate a successful multi-cultural mediation.

In cross-border or cross-cultural parental abduction mediations, mediators must be able to: “(1) strike the proper balance between people whose culture separates people from their problems and a culture that must give equal attention to both the person and the problem; (2) understand when the parties' culture calls for open self-disclosure when it is better to put a person behind closed doors, usually as a means of saving face; (3) know when a person's culture will require that person to take individual ownership of actions versus when the person comes from a more collectivistic culture that requires more than just that person to participate in the process -and appropriately involve other stakeholders and decision-makers in the process; (4) strike a balance between the parties who need immediacy, directness, decisiveness and those who need to take more time, allow adjustments to be made, accommodations to emerge, and acceptance to emerge; (5) know and understand the cultural underpinnings of the parties' opening positions - do the start off with bottom-line positions or do they inflate what they ask for, under the assumption that it would help them to reach a more agreeable resolution; (6) know how to manage the parties' cultural expression of their emotions- some cultures simply cannot work in a situation where emotion is expressed very openly and directly; others need this open expression to be able to then move past the emotion to concrete 
resolutions; (7) understand the cultural use of "yes" and "no"; and (8) know how the culture dictates the final agreement -will implementation of the agreement simply take care of itself, or does this culture dictate ongoing interpretation and open channels for problem-solving". ${ }^{125}$

Another handicap related to International Child Abduction training, is that the mediator must learn as well how to manage domestic violence. ${ }^{126}$

As well, and opinion that we sustain and firmly emphasize is that in order to reduce the difficulties in a context of kidnapping, the mediator must be acquainted with online dispute resolution, as the best communication means between the parties who are in different countries.

In the case of co-mediation, maybe it is important to aim for balance: a woman and a man; a legal professional and a representative from the psycho-social field; one from the nationality of each parent and if this doesn't work one of them should be bi-cultural; one of them should be bi-lingual, among others.

The mediation process needs to be expedited and for this reason the mediator needs to be prepared for this intense work, maybe in one or two weekends ${ }^{127}$ when parties are separated by long distances.

The benefits of an online forum are only effective if the mediator has been properly trained to employ this medium, practically demonstrating empathy and capability to notice the incongruities, in this context, through textual communication, for instance. ${ }^{128}$ The mediators must be trained to effectively employ the textual communication - develop a clear writing style and good writing habits - and online forum — seeing the impact of

125 Kucinski, supra n. 66.

126 There are divided opinions on whether it is convenient or not to mediate in cases of domestic violence. We stand for mediation in general, in cases of domestic violence by involving especially trained mediators.

127 Before a mediation session a timeline and game plan for the mediation is very difficult because there are a lot of think around a international child abduction case such as "both parents may have filed a petition seeking the return of the child, a court case, or even criminal charges, and such pre-existing process will affect the timeline under which the mediation must be completed. If the mediation requires interpreters, the amount of time needed to properly conduct the mediation will increase. If the mediator must stop the process to have documents translated...”. Kucinski, supra n. 116, 307.

128 "As part of this adaptation, a textual communication has been created to convey emotions. Smiley faces '(SEE SYMBOL)' are used to convey a positive emotion, while 'ALL CAPS' is used to demonstrate anger or strength of emotion". AM Braeutigam, "Fusses that Fit Online: Online Mediation in Non-Commercial Contexts”, (2006) 5 Appalachian Journal Law, 291. 
the technological culture - to be able to create and maintain the trust and rapport between the parties and the mediator that is crucial for successful mediation. ${ }^{129}$

Summarizing, an international family mediator must be competent to address the substance of a case that is: international, cross-jurisdictional, cross-cultural, emotional, is concerned about the child well being, be able to do so with ethics and professionalism ${ }^{130}$ and why not, in an online dispute resolution context.

\section{B. Cultural Diversity}

Next to the diversity of elements outlined above as challenges for the prevention of international child abduction, and within the specialization or training international family mediation the "culture" plays a special role ${ }^{131}$ and the impact that intercultural issues may have on the mediation need to be taken into account.

Definitely in cases where an international abduction has already taken place, mediation can also be an effective tool, particularly when conducted in a way that is culturally neutral and respectful of the need for quick resolutions in child abductions. ${ }^{132}$

The culture has been incorporated recently into mediator trainings and this is not a mere coincidence. We are convinced that a successful international family mediation requires special training in this field.

It is evident that today's world has changed with respect to past times, even the recent past; the globalization and the economics or personal in-

129 Gibbons, L. J., "Cybert-Mediation: Computer-Mediated Communications Medium Massaging the Message”, (2002) 32 N.M. L. Rew. 35.

130 Kucinski, supra n. 116, 308.

131 In this context, the "Children's Magna Charter", that is, the United Nations Convention on the Rights of the Child of 1989, Article 20(3) provides that "due regard shall be paid to the desirability of continuity in a child's upbringing and to the child's ethnic, religious, cultural and linguistic background"; Article 29(c) provides for "the development of respect for the child's parents, his or her own cultural identity, language and values, for the national values of the country in which the child is living, the country from which her or she may originate, and for civilizations different from his or her own", Article 30 "child belonging to... a minority or who is indigenous shall not be denied the right, in community with other members of his or her group, to enjoy his or her own culture, to profess and practice his or her own religion, or to use his or her own language".

132 http://travel.state.gov/abduction/about/whatsnew/whatsnew_3859.html (march 21,2013) "Mediation. Settling out of Court". 
terchanges poses great challenges for international family interaction. In this context, we can express that cultural diversity is a fundamental factor to understand it, ${ }^{133}$ recognized and valued as part of a person's identity. ${ }^{134}$

Culture has been defined in numerous ways but for the purposes of mediation we followedTing-Toomey definition like "A complex frame of reference that consists of patterns of traditions, beliefs, values, norms, symbols, and meanings that are shared to varying degrees by interacting members of a community - iceberg metaphor-. ${ }^{135}$

One of the features in a cross-border family mediation is the fact that the parties, in general, have different cultures and it is very necessary to know their values and expectations regarding many aspects of the exercise of parental responsibility, for instance, the education, or the religious care ${ }^{136}$ of their children. Indeed, culture has different elements as there are nationalities, religions, ethnicities, organizations, or occupations ${ }^{137}$ which are necessary to know for good management when we talk about international family mediation and all this not leaving aside those cases such cases where laws in the country of origin regarding children custody have a religious or cultural foundation that are not in accordance with human rights principles. ${ }^{138}$

133 But not the unique, "cultural considerations are so complex and ever-changing in our globalized world that defining a person by identity to a single culture and using that identity to predict values or behavior is prone to error. However, because it is helpful to have clues about how our negotiating counterparts perceive the world and perhaps value things differently than us, cultural variations should be considered"(paragraph underlined not by the author) J Folberg, Resolving Disputes: Theory, Practice, and Law, USA, Aspen, 2010, p. 182.

134 Kovach, K., Mediation in a Nutshell, St. Paul, Thomson-West, 2003, p. 55.

Quoted Folberg, supra n. 129, 182, the reflection it is that "cultural considerations are so complex and ever-changing in our globalized world that defining a person by identity to a single culture and using that identity to predict values or behavior is prone to error" but in their discurs the idea is that cultural variations should be considered.

135 Ting-Toomey, Stella, Communication Across Cultures, New York, The Guildford Press, 1999, p. 10, Cit. Matsuno, Yuki and Neallani, Shelina, "Family Mediation, Distance Mediation, Intercultural Mediation -What does any of this have to do with Maintenance Enforcement? A Discussion Paper" presented in Recovery of Maintenance in the EU and Worldwide, Heidelberg, 5-8 March, 2013.

136 Bruch. C., "Religious Law, Secular Practices, and Children's Human Rights in Child Abduction Cases under the Hague Child Abduction", 33 N.Y.U. Journal International Law \& Policy, 2000, pp. 49-51.

137 Avruch, Kevin, Culture and Conflict Resolution, 59-60 (1998) Cit Kucinski, supra n. 66, 556.

138 Schuz, Rhona, "The Relevance of Religious Law and Cultural Considerations in International Child Abduction Disputes”, Journal of Law\& Family Studies, vol. 12, 2010, p. 453. 
It seems trivial, but each culture does have a sign code of its own; verbal or non-verbal, ${ }^{139}$ symbols that connect people who are members of one group specifically.

The mediator's role in those cases is crucial because it can reveal the differences between a good or bad communication on the middle of the mediation process, and it is true that, "an aspect of culture that has a particular impact upon the mediation process is communication", ${ }^{140}$ that is, the culture affects the communications between parties and mediator and may affect the way of defining a family ${ }^{141}$ and what is the best interest for a children, ${ }^{142}$ as a fundamental principle. Therefore mediators conducting mediation in such cases should have a good understanding of cultural background of the parties and the recognition of the other party's cultural differences. ${ }^{143}$ Perhaps co-mediation is a good exercise to bring about successful international family mediations ${ }^{144}$ keeping in mind the time necessary for a international family mediation with cultural issues. ${ }^{145}$

According to Kucinski "Culture implicates the way that two parents are communicating. It will also implicate the way a mediator communicates

139 Satir, Virginia, Conjoint Family Therapy, 3rd ed., Palo Alto, Cal., Science and Behavior Books, 1983, pp. 9 and ss.

140 Kovach, supra n. 134, 55.

141 Without forget that families develop their own norms and signals for communicating "many of which are outside the radar of outsiders". Kucinski, Melissa A., "Culture in International Parental Kidnapping Mediation”, Pepperdine Dispute Resolution Law Journal, University School of Law, USA, 9, 2009, p. 573.

142 Augsburger, David W., Conflict Mediation Across Cultures: Pathways \& Patterns, Westminster/John Knox Press, 1992, p. 191.

143 Guide to Good Practice under the Hague Convention of 25 October 1980 on the Civil Aspects of International Child Abduction. Mediation. SI, 2012/31. Domínguez, Jessica R., "The Role of Latino Culture in Mediation of Family Disputes", Journal of Legal Advocacy \& Practice, 1, USA, 1999, pp. 154-171.

144 Another think is employ a cultural broker or interpreter, first in order to introduce the cultural factor and second, why not, used to correct a power imbalance between the parties.

It is important to reinforce that in cases of mediating international parental abduction o kidnapping, the German model utilizes an attorney-mediator and a therapist-mediator as co-mediators; "it can be helpful to partner with another third-party intervener of a different culture who can guide you, in addition to the parties, in seeing things from a new perspective”. Kucinski, supra n. 66, 572.

145 Bear in mind that under the 1980 Hague Convention, the objective is to have a final resolution within six weeks of commencing a Hague case. 
with each parent, and his or her interpretation of the parent's verbal and non-verbal messages". ${ }^{146}$

As we may see, when we talk about the specialization of the international family mediator, we refer to aspects like the cultural challenges or the linguistic challenges, for instance. "Knowledge of some of the nuances of a particular culture may assist the mediator to know when and how to modify the process" ${ }^{\prime 147}$ and this is true because communication, and understanding can make a great difference. ${ }^{148}$ Part of the dispute involves lack of a realization or recognition of another person's cultural differences. ${ }^{149}$ In those cases, in spite of the mediator's neutrality and impartiality he could assist actively the parties to understand the differences in perceptions.

According to doctrine, on one hand, the cultural issues usually have more to do with form than with substance ${ }^{150}$ — maybe more so in business issues - in general, avoiding miscommunication is the goal, with o without reaching deals, and the preparation for those challenges is crucial.

On the other hand, we must bear in mind the way the parties perceive the relationship, or the family relations ${ }^{151}$ in order to be able to help, as well as to promote good understanding. Here it is important to underline there are numerous cultural communication considerations to take into account like "what type of volume, pitch, rhythm, tempo, resonance and tone...", ${ }^{152}$ or no verbal language, for example, salutation in Japan, bowing and lowering the head and the sight; loudness in conversations, even trivial ones in

146 Kucinski, Kucinski, supra n. 66, 558.

147 Kovach, supra n. 134, 55.

148 Kovach, supra n. 134, 56, express that much cultural diversity exists in terms of communication and put as example the eye contact in most Western cultures in front of East cultures (a sign that you are listening to the speaker or as insulting a lack of respect for the individual).

149 Kovach, supra n. 134, 56.

150 Shell, G. R., Bargaining for Advantage. Negotiation Strategies for Reasonable People, USA, Penguin Books, 2006, p. 20.

151 We are thinking around the "Families News Structures" (surrogacy maternity, adoption, same-sex parents, monoparental family, etc) and the necessity of change the "perspective" around the notion of "families" and the context for the mediation, family mediation, international family mediation and the role of the culture inside. González Martín, N., supra n. 1; González Martín, N., "Maternidad subrogada y adopción internacional”, Fertilización Asistida. Reflexiones Interdisciplinarias, México, UNAM, 2012.

152 Kucinski, supra n. 66, 562. 
Israel; to avoid touching or greeting someone with the left hand, a sign of impurity for people in India. The meaning of bargaining for an item being purchased in a Moroccan market; initiating a good, friendly relationship with your hosts by buying a round of drinks (or simply a firm handshake) in Australia. To shake hands instead of kissing when people are introduced in the US, or to be late for a mediation session without this meaning a lack of interest or respect, but something that maybe simply a cultural feature.

Finally, it is important to express that a parent's cultural traits may dictate that he must consult with third parties in his cultural group prior to entering into a binding agreement. ${ }^{153}$

In order to achieve those goals, a specific training is necessary. To be bi-lingual is very important for this topic and the quoted co-mediation requires this, but being "bi-cultural" is likewise important. A choice of specialist mediators makes the difference. "A model that has been successfully followed in some mediation schemes and which was specifically developed for cross-border child abduction involving parents from different States of origin is that of 'bi-national' mediation"154. In this context we understand bi-national could as well stand for Bi-cultural.

\section{Domestic Violence}

Currently many international parental child abduction cases, involve severe allegations of domestic violence. ${ }^{155}$

Domestic violence can take many forms: 1) physical or psychological abuse - it can extend to sexual, emotional and financial abuse-; 2) child abuse and/or partner abuse; 3) single isolated incident or sustained and recurring pattern. ${ }^{156}$

153 Ibidem, p. 560.

154 Franco.German Project of Bi-national Professional mediation (2003-2006); US-German Bi-national Mediation Project; Polish-German Bi-national Mediation Project. Cit Guide to Good Practice under the Hague Convention of 25 October 1980 on the Civil Aspects of International Child Abduction. Mediation. SI, 2012/32.

155 There are several works about this subject that we can mention, apart from the aforementioned: Weiner, M. H., "International Child Abduction and the Escape from Domestic Violence”, Fordham Law Review, USA, November 2000, 593-659; Wheeler, L., "Mandatory Family Mediation and Domestic Violence", Southerns Illinois University Law Journal, USA, Spring 2002, num. 26, 559-571.

156 And the domestic violence has a cycle of violence: a) a tension- building phase ; b) an 
The Hague 1980 Convention provides a defense or exception to the return of the child to his habitual residence by demonstrating that the child would be in grave risk of harm by being returned. The Hague Convention provides these defenses or exceptions to the return of the child to his habitual residence, once a petitioner demonstrates that the removal or retention of the child was wrongful, when, among others, the return would result in great risk of physical or psychological harm (article $13(\mathrm{~b}))^{157}$ and where a child abduction has occurred, Central Authorities are under the obligation 'to prevent further harm to the child or to interested parties by taking or causing provisional measures to be taken ' in accordance with Article 7.(2) (b) of the Hague Convention.

The problem at this point is the "use" and, most importantly, the "abuse" of these allegations, actually, in the context of domestic violence, for instance, at times unfounded. ${ }^{158}$

In international child abduction cases, allegations of domestic violence are not rare. Some of these accusations may prove to be unfounded but others are legitimate and may be the reason why the taking parent left the country with the child. Domestic violence is a very sensitive issue and needs to be dealt with accordingly. ${ }^{159}$

incident with an escalation of violence; c) a reconciliation phase with forgiveness and promises. Guide to Good Practice under the Hague Convention of 25 October 1980 on the Civil Aspects of International Child Abduction. Mediation. SI, 2012/72, 73.

157 The "grave risk" (based, generally, in domestic violence) exception found under this article 13 (b) is the most frequently asserted defense in application cases. Conclusions and recommendations adopted by the Council on General Affairs and Policy of the Conference (9-11 April 2013), Hague Conference on Private International Law, n 18 "In relation to the 1980 Child Abduction Convention, the Council welcomed the progress in the preparation for the Working Group to develop a Guide to Good Practice on the Interpretation and application of Article 13 (1) b) of the Convention, and invited the Permanent Bureau to convene two meetings of the Working Group and to report to Council in 2014", www.hcch.net.

158 Part II of the Sixth Meeting of the Special Commission to review the practical operation of the 1980 Hague Convention and 1996 Hague Convention has recommended that further substantive work in... "the application of the Article 13(1)b) defence, including allegations of domestic and family violence, in connection with return proceedings under the 1980 Convention, possibly as a Guide to Good Practice", See "Report of the Further Work Recommended by the Special Commission on the Practical Operation of the 1980 Child Abduction Convention and the 1996 Child Protection Convention”, Prel. Doc. No 12, March 2012, p. 4. www.hcch.net.

159 Guide to Good Practice under the Hague Convention of 25 October 1980 on the Civil Aspects of International Child Abduction. Mediation. SI, 2012/73. 
Although article 13 (b) was drafted when most child abductors were fathers and before domestic violence was a salient public concern, it has been interpreted to protect victims of domestic violence and their children. ${ }^{160}$ The proliferation of domestic violence allegations is such that one must exercise great caution so as not to use that resource without thinking of the consequences it has for all parties involved, thinking, first and foremost, on the child; otherwise this would undermine the Convention's twin goals of deterring child abductions and returning children swiftly. ${ }^{161}$

Yet another question is if it is at all possible or convenient to mediate in cases of domestic violence? The authors are divided. Some experts consider mediation in such cases generally inappropriate, for a number of reasons: 1) the moment of separation from the abuser is the most dangerous time for the victim at risk or 2) victims of domestic violence often have difficulties in advocating their own interests when facing the abuser. Others [many] experts are against a general exclusion of mediation in cases involving domestic violence, provided that well-trained professionals knowledgeable in the subject matter are involved. ${ }^{162}$

We think it is indeed necessary to mediate in such cases because, on one hand, the problem is too big to rule out the possibility to choose mediation to solve these issues and the other hand, ${ }^{163}$ maybe the victim of domestic violence may also feel more comfortable in the controlled and confidential mediation environment. ${ }^{164}$

But the analysis goes beyond this, because one thing are the violence allegations under the domestic context and other thing are cases of violence in an international context.

160 Browne, supra n. 104, 1213. Some courts but not all.

161 Browne, supra n. 104, 1202.

162 Guide to Good Practice under the Hague Convention of 25 October 1980 on the Civil Aspects of International Child Abduction. Mediation. SI, 2012/73. About this topic, See "Guidelines for Mediating International Family Matters”, Task Force on International Family Mediation, ABA/ SIL, 12 February 2013.

163 Mediating domestic violence seek that the parties be in a power balance with the help or lead specialized professionals mediators "as reunite has found, when its mediators have proceeded to mediate these cases, the victim often becomes empowered and finds a voice, and grows during the process, more so than in a courtroom”. Kucinski, supra n. 118, 318.

164 Idem. 
Mediating disputes involving domestic violence allegations has proven exceptionally challenging and highly controversial in the domestic context ${ }^{165}$ and, likewise, in the international context attending the states' incompatible social and cultural norms, among others, can endanger the parties and adversely impact the mediation process and, accordingly, the outcome; that is, every compelling reason not to mediate cases involving domestic violence in the domestic context is amplified in the international context. ${ }^{166}$

Definitely, one may intuitively perceive the need to mediate in cases of alleged domestic violence so as not to double discriminate against the individual who endures this situation - i.e. being a victim and not having access to an ADR process. Yet proper guidance is required to help the victim understand and address this critical question or situation.

In this context, in relation to the mediation process there are many ways in which it can be adapted to protect and empower the victim. ${ }^{167}$

Finally, according with the Guide of Good Practice, mediation must not put the life or safety of any person at risk, especially those of the victim of domestic violence, family members or the mediator. The choice between direct and indirect mediation, ${ }^{168}$ the mediation venue and the mediation model and method ${ }^{169}$ must be adapted to the circumstances of the case. Where mediation is considered suitable in a case involving an issue of domestic violence, it needs to be conducted by experienced mediators specially trained to mediate in such circumstances. ${ }^{170}$

165 Alanen, supra n. 32, 51.

166 Ibidem, p. 52.

167 Guide to Good Practice under the Hague Convention of 25 October 1980 on the Civil Aspects of International Child Abduction. Mediation. SI, 2012/73.

168 Mediation in which both parties directly and simultaneously participate in the mediation sessions with the mediator (face-to-face or long-distance with online tools.

169 We refer about single or co-mediation or a bi-cultural/ bilingual mediation.

170 Guide to Good Practice under the Hague Convention of 25 October 1980 on the Civil Aspects of International Child Abduction. Mediation. SI, 2012/75. 


\section{Potential Online Dispute Resolution ${ }^{171}$ in International Parental Child Abduction and Mediation: Distance ${ }^{172}$ and Communication Technologies ${ }^{173}$}

\section{We wish to note, first of all, that the present section deals with a topic that is not included in the Guide to Good Practice of the 1980 Hague Conven- tion, but it is of utmost importance and hence the tendency to propose the implementation of ODR or electronic tools ${ }^{174}$ when we speak of cases}

171 We must highlight that the Facilitated Resolution (TFR) "only covers a fraction of ODR. Specifically, TFR refers to processes whereby a lot of complaints filed by customers against a company go through several filters designed to resolve as many cases as possible without requiring the respondent (the company) to participate. For example, the consumers' case can be resolved based on the policy they agreed to, or based on standard exchange negotiation". Conversation with Loïc E. Coutelier, Director of Arbitration and Product Manager MODRIA (https: //www.modria.com).

172 For us distance [mediation] and Online Dispute Resolution or ODR are directly relationaded but some authors difference between "distance Mediation" and “ODR", Matsuno and Neallani express: "The term 'distance mediation' was used because the term 'ODR', or online dispute resolution, typically referred to disputes that were facilitated by some form of computer application. Although the term 'ODR' now includes tools that do not use computer technology, such as the phone or video conferencing, we have continued to use distance mediation 'because its focus is more on the element of 'distance' than on the specific technology used in bridging that distance for the parties" Matsuno, Yuki and Neallani, Shelina, "Family Mediation, Distance Mediation, Intercultural Mediation -What does any of this have to do with Maintenance Enforcement? A Discussion Paper" presented in Recovery of Maintenance in the EU and Worldwide, Heidelberg, 5-8 March, 2013.

173 The term technology is used to refer to information and communication technologies that can be any of arrange of electronic communication tools, including regular landline and cell phones, teleconferencing, email, text messaging, custom text-based applications, video or web conferencing — with, computing technologies_- The term "platform" or "application" is used to refer to a particular piece of computer software or web conferencing technology. An another thing is synchronous and asynchronous technologies; the synchronous technologies are those that enable people to communicate in real time, or at the same time while they are in different places -for instance, video and web conferencing-, the asynchronous technologies, allow communication over a period of time, in consecutive time, while people are in different places, for instance email and discussion boards. J Susanna, Mediating from a Distance: Suggested Practice Guidelines for Family Mediators (British Columbia Mediator Roster Society, 2010), online: http: / / www.mediatebc.com /PDFs / 1-14-Family-Mediation---FAQs / Mediating_From_a_Distance_2nd_Edition_Nov-2012.aspx.

174 Conclusions and recommendations adopted by the Council on General Affairs and Policy of the Conference (9-11 April 2013), Hague Conference on Private International Law, n 21, expresses in these sense that "The Council welcomed the recent developments in relation to electronic tools under the 2007 Child Support Convention and 1980 Child Abduction 
of international abduction, maybe the ODR could provides a solution for practical issues such as migration barriers, conflict of law ${ }^{175}$ or the recognition and enforcement on cross border voluntary agreement, which present major challenges to private international law indicated in previous sections.

Likewise, it is important to highlight that the current debate about the necessity for the implementation of ODR or the debate about it, for instance, where the mediation is commonly referred to as ADR and not as a primary form of dispute resolution ${ }^{176}$ will be outdated shortly and we will find ourselves asking why did such doubts ever arise.

That way, keeping in sight the current debate, although mediation strives to make parties meet, long distances as well as the potential for confronta-

Convention and encouraged States to support the work in this area" concretely electronic tools related of the 1980 Convention are: INCADAT, INCASTAT and ichild.

On the other hand, in the Council on General Affairs and Policy of the Conference (8-10 April 2014) it was sent the Report on the Experts' Group meeting on Cross-border Recognition and Enforcement of Agreements in International Child Disputes (from 12 to 14 December 2013) and recommendation for further work" (Prel. Doc. No 5 of March 2014): “25. The Experts' Group concluded that there was a need for those concerned to be provided with a non-binding "navigation tool" to assist them in securing cross-border recognition and enforcement of "package agreements" within the existing legal framework, and noted the additional benefit of a binding instrument to provide recognition and enforcement of the complete "package” as a “one-stop shop”; and more specifically, this Experts' Group proposed R\&C “11. The Experts' Group recognised the need for those concerned, including parents, mediators, lawyers and judges, to be provided with a "navigation tool", e.g., non-binding principles or guidelines, to assist them in securing cross-border recognition and enforcement of "package" agreements in the existing legal framework". For us, between this "navigator tools" is possible to include in this subject the ODR. The Conclusions and Recommendations adopted by the Council in April 2014, expressed by R\&C 5, “... The Council invited the Permanent Bureau to expand the composition of the Experts' Group... The Permanent Bureau will report to Council in 2015”. www.hcch.net.

175 Just to mention a situation where the benefits of ODR versus the traditional legal system are clearly exposed, do not forget two issues, for example: in cross border cases the enforcement is too complex (offline) and no need to resolve issues of jurisdiction (online). Rule, Colin, Power Point “Online Dispute Resolution and Internet Justice”, in Resolving our Differences in the $21^{\text {st }}$ Century: A Conference on Online Dispute Resolution, Stanford Law School, April 19, 2013. However it is not clear how ODR solves problems of jurisdiction and enforcement since it will often be necessary to obtain a consent order from a court to ensure that the agreement is enforceable in both countries.

176 Kaufmann-Kohler, G., Online Dispute Resolution: Challenges for Contemporary Justice, The Nederlands, Kluwer Law International, 2004. 
tion in this type of cases, could make online dispute resolution (ODR) a valuable tool worth considering. ${ }^{177}$ Mediators are increasingly using ODR as a mediation technique. ODR was originally introduced as tool for ecommerce disputes, ${ }^{178}$ however it has become increasingly important in family custody disputes. ${ }^{179}$

The main differences between an international e-commerce dispute and an international child abduction is the fact that the latter does not originate online but this factor is not necessarily determinant to reject this mechanism of ODR in cases involving international families. Online mediation occasionally faces criticism stating that it imposes a distance on the parties. However this is not the case; on the contrary, the Internet brings people close together. ${ }^{180}$

Therefore, we will turn our attention to other dynamics in mediation and the use of communication technologies to mediate from a distance.

Technology is around the world, in some countries with more potential and other countries with less presence, but the technology is here and opens the possibilities of communication and we need to use for the dispute resolution in international child abduction case too.

Many mediators prefer to mediate a dispute face-to-face for multiple good or positive reasons such as to be able to perceive the hands or feet motion of the client and thus detect some emotion and work with this in the mediation process ${ }^{181}$ but is often times impossible to do due to the cost to travel, the difficulty in getting a flight from the origin country, the impossibility to obtain a visa, as well as criminal charges, etc. Therefore, some mediators seek to help their clients through the numerous electronic media, for instance, e-mail, video-conference or specific platform established for the civil, commercial or family mediation. ${ }^{182}$ Technology enables us

177 Katsh, E., On Line Dispute Resolution. Resolving Conflicts in Cyberspace, San Francisco, Jossey-Bass, 2001.

178 Albornoz, supra n. 120.

179 Cunha, E., "The Potential Importance of Incorporating Online Dispute Resolution into a Universal Mediation Model for International Child Abduction Cases", Connecticut Journal of International Law, 2008, 158.

180 Gibbons, supra n. 129, 43.

181 And maybe it is important to do a face-to-face in the mediator's initial communications with each parent but the successive meetings could perfectly be held through electronic media.

182 https://www.modria.com. 
to expand the number of deals — or at least communication leading to deals - in cross-border family disputes. Definitely technology could aid the parents, where, despite the parents' best efforts to be present in the same room during mediation, they could not; despite family mediation advocates' strongly held desire to have mediations face-to-face ${ }^{183}$ — we tend to think about the face-to-face meeting for an "effective" mediation- ${ }^{184}$

International child abduction is a complicated legal issue marked by urgency and poor communication so the support of international organizations like the Hague Conference on Private International Law is essential. This paper is focused on the actions conducive to the development of mediation services to assist where appropriate in the resolution of crossfrontier disputes concerning kidnapping by one of the parents where ODR should also be present.

\section{a. Subjective Elements}

Cross-border mediations involve many actors, among others: 1 . One o two mediators; 2. Parents (biological, adoptive or de facto); 3. Lawyers; 4. Third parties; or 5. maybe an interpreter and to have all those actors together presents on the same day in the same room is practically impossible for many reasons such as the physical distance. In those cases a mediation may require the use of technology to facilitate communication ${ }^{185}$ like a phone, e-mail, Internet, skype or software to help the parties co-parent, ${ }^{186}$ even an On Line Dispute Resolution platform, etc.

Cross-border family mediations need, additionally, a "technological savvy", particularly if the use of technology implies writing (i.e. e-mail), ver-

183 Kucinski, supra n. 116, 313.

184 About the commonly cited challenges and the ODR as an effective substitute for face to face, see Sela, Ayelet, Power Point "ODR System Design: Lessons from Research and Practice”, Resolving our Differences in the $21^{\text {st }}$ Century: A Conference on Online Dispute Resolution, Stanford Law School, April 19, 2013.

185 Kucinski, supra n. 116, 307.

186 "Besides e-mail and telephone, parents may use web-based collaboration software, such as 'Family Wizard', which allows parents to maintain one database for notes on children's doctors, school plays, playdates, or other activities". Melamed, J., Divorce Mediation and the Internet, MEDIATE.COM, Jan. 2002, http: / /www.mediate.com/articles/melamed9.cfm. Cit. Kucinski, supra n. 116, 314. 
sus speaking (i.e., video or phone conference), the mediator should have clear and effective writing skills". Apart from these skills, he may have to listen, reflect or empathize, skills that are not necessarily learned through training or a formation process. The standards and credentials for mediators should include these technological skills to be able to perform a crossborder mediation. ${ }^{187}$

Family mediators are always seeking ways to expeditiously and efficiently mediate their cases and the use of technology can be an answer.

The advantages or benefits to using technology in mediation are numerous and they vary according to the interlocutor.

Mediators can: 1 . Advertise their services; 2 . Find information quickly about laws, for instance; 3. Communicate separately or jointly with the parents in a mediation; 4. Send documents; 5 . Send an agreements' draft and "discuss" about it even in "real time" by chats; 6 . Caucus, that is, conduct separate sessions for the parents and save time if it is done on line; 7. To "Bridge distances" and 8 . Reduce time barriers and all of it consequently deescalate contentious emotions brought on by the parties being in the same physical space. ${ }^{188}$

Parents or clients, judges, Central Authorities can: 1. Research the mediator's competency or 2. Research about the selected mediator; 3 . Avoid a non-verbal language that may be harmful or stressful face-to-face, ${ }^{189}$ this benefit can be especially applicable for custody disputes. ${ }^{190}$

In other words, the use of the technologies and specifically, On Line Dispute Resolution has several benefits, apart from early resolution: 1 . It is more effective; 2 . It is automatable; 3 . Saves costs and 4. Improves satisfaction of the parties involved. ${ }^{191}$

187 And inside the mediation, instead, those mediators can be facilitative or evaluative or merely to do mediation where both parents are in a country that is a signatory to the Hague 1980 Convention, etc.

188 Cunha, supra n. 179, 178.

189 Non-verbal or “(B)ody language can be misinterpreted and can be negative” and refers certain attitudes as crossed arms with a significant of refuse. Cunha, supra n. 179, 174.

190 Braeutigam, supra n. 126, 174. Taking the conversation into a text-based environment removes the possibility of negative behavior and body language escalating the conflict and this benefit can be especially applicable for custody disputes.

191 Rule, Colin, Presentation Power Point "Online Dispute Resolution and Internet Justice" in Resolving our Differences in the $21^{\text {st }}$ Century: A Conference on Online Dispute Resolution, Stanford Law School, April 19, 2013. 
But, maybe, not everything is positive with the use of technologies. One of the main disadvantages of using technology in mediation can be the fact that we must also acknowledge that technology may be inaccessible to many parents due to expense, location, education or cultural perception. ${ }^{192}$ This is a goal for the implementation of the so called On Line Dispute Resolution (ODR) too because "people who are not accustomed to this form of communication may be unable to adapt rapidly enough to effectively resolve a dispute, where there is heightened stress and pressure to resolve a matter, with emotions running higher than in normal custody matters". ${ }^{193}$

The online environment, as it can be seen, is a double-edged sword but, in our view the scale tips towards the advantages. For instance, regardless of the fact that gestures are a guide and a tool for the mediator's better understanding of a situation, it is not possible to perceive or discern in a mediation conducted over the telephone or e-mail the bad gestures of the parents, which are always harmful when trying to agree about your marriage or your child. In international child abduction cases is necessary work towards a positive and long lasting relationship between the parties in order to avoid re-abductions too, the ODR in those cases can help to find the necessary communication. ${ }^{194}$

Furthermore, technology may aid the mediation in an international parental child abduction with domestic violence allegations and "may also allow a victim to have a voice, to not fear repercussions, and to allow him or her to feel secure in their communications". ${ }^{195}$

In some jurisdictions it is possible for the mediator to hear a child, with sufficient age and maturity, and for the mediator, when the mediation is not conducted where the child is located, to know and to see the minor, which is likewise significant. Children tend to have technologically savvy and may feel comfortable texting or e-mailing a mediator.

On the other hand, a special handicap for mediation and technology maybe the cultures involved, that is, "while technology may be useful in some mediations, parents may be unable to exhibit their cultural traits through

192 For instance, present their evidence in person.

193 Kucinski, supra n. 116, 316.

194 Pawlowski, supra n. 72, 304.

195 Kucinski, supra n. 116, 318. 
nonverbal communication, imperceptible through some technologies". ${ }^{196}$ Yet, the problem lies not in seeing the gestures, but rather in knowing and understanding those cultural gestures or signs. ${ }^{197}$

Technology offers a number of benefits to its users: parents can communicate in a safe environment, where conversations are transparent and recorded, the possibility of confrontation of a face-to-face is eliminated and where the child is not placed in a situation in which he might interfere with parental communication.

\section{b. Some Experiences: National Programs}

Mediation in international cases needs a special treatment because there are language and cultural barriers and different legal systems that may complicate a resolution. For that reason, many nations have employed mediation teams with two mediators, one from each country involved, with a special preparation. A very effective model indeed but, maybe, at a prohibitive cost. In order to address these issues, several countries have established (bi)national programs in order to minimize costs -economic and emotional costs- for parents and ensure high quality mediation. ${ }^{198}$ United Kingdom and Germany have established non-profit organizations; ${ }^{199}$ in

196 Ibidem, p. 319.

197 About others cultural traits, like "high-context" — emphasis on context of communication; tone, body language also provide meaning; more examples of indirect speech, etcand "low-context" - emphasis on written/spoken words; specificity and clarity are valued, etc - communication or the sens of "collectivists" versus "individualist". See Y. Matsuno and S. Neallani, "Family Mediation, Distance Mediation, Intercultural Mediation - What does any of this have to do with Maintenance Enforcement? A Discussion Paper", presented in Recovery of Maintenance in the EU and Worldwide, Heidelberg, 5-8 March, 2013, Appendix A, p. 23 and Michelle Lebaron \& Venashri Pillay, Conflict Across Cultures: A Unique Experience of Bridging Differences, 35 tbl.3.1 (2006) Cit Kucinski, supra n. 116, 319-320.

198 Vigers, S., Note on the development of mediation, conciliation and similar means to facilitate agreed solutions in transfrontier family disputes concerning children especially in the context of the Hague Convention of 1980, Doc. Prel. No 5.

199 A non-profit institution or organization can seek funding and needs to be non-affiliated to any government to remain impartial (and trustworthy) and has to seek a list of mediators who are the highest qualified as well as to conduct training sessions to give post mediation follow-up. We are thinking about the structure, from theory to practice, implemented throughout many years International Adoption Collaborative Entities, through the 1993 Hague Convention on minors protection and cooperation in International Adoption; thus 
Montreal, Quebec, the court runs a mediation program with a little cost to the parents, among other countries. ${ }^{200}$

Germany $^{201}$ has come a long way in bi-national projects ${ }^{202}$ about crossborder child custody mediation ${ }^{203}$ and Germany engaged other countries, in subsequent years, in structuring its mediation standards, ${ }^{204}$ especially noteworthy is the work conducted by the Bundes-Arbeitsgemeinschaft fur Familien-Mediation (BAFM) ${ }^{205}$ At present, "mediators in any German cross-border family mediation project are trained for a minimum of 160 hours as family mediators, plus advanced training in child abduction and custody cases". ${ }^{206}$ This German structure focuses on resolving the core problem underscoring an international parental child abduction, that is, what the child's daily life looks like with parents living in different countries, therefore Germany's structure is comprehensive in the sense that mediation involves more than the mediation itself. ${ }^{207}$

avoiding at all times undue profits and favoritism among the mediators list as well as their permanent training and updating.

200 There are others context or other countries that have a important development in this field, that is, in international family mediation; for instance, we can name in France, the Agency for Assistance to Families in International Mediation (MAMIF) http: / / www.enleve ment-parental.justice.gouv.fr.

201 Since September 1, 2009, Germany requires that, in family court proceedings regarding matrimonial and parental responsibility, the judge may order the parents to a mediator to be informed about the mediation process but this is not a requirement that the parents attend mediation. http://www.hcch.net/upload/wop/mediation09_de.pdf.

202 Germany/France; Germany/England and Germany/USA.

203 EC Honorable "Mediation Projects in Hague Cases: Developments in Germany", (2007) 7 The Judge's Newsletter on International Child Protection, 49, http: / / www.hcch.net / uploadnews2007.pdf.

204 Kucinski, supra n. 21, 82.

205 Since 2002, the BAFM has administered a network of mediator who help settle international conflicts involving bi-national parents and their children in accordance with the 1980 Hague Convention and since 2007 this project has been carried out in cooperation with Germany's Federal Mediation Association (Bundesverband Mediation -BM-). Paul, supra n. 61,42 .

In 2008, both organizations, BAFM and BM, founded MiKK -German acronym for 'Mediation in International Conflicts involving Parents and Children-, as an independent nongovernmental organization to continue and further their efforts. See Wright, Walter A., "International Peacemakers. Mediating Cross-Border Child Custody Disputes in Europe: MiKK Blazes the Trail”, The Texas Mediator, USA, p. 16.

206 Kucinski, supra n. 10, 301.

207 Kucinsky, supra n. 21, 82, 83. Even moreover "an interim solution is sought (e.g., 
In that sense, the German structure is established by the co-mediation with a balance: a woman and a man; a legal field and a psycho-social field; it is preferred, to have a German mediator and the other from the country of origin of other parent or at least a mediator who speaks the language of the other partner and the mediation is held in the country where the child is located at present with the intention to enable contact, as well, among the left behind parent and the child or children, between mediation sessions. Germany highlights the necessity to have sufficient knowledge about cultural idiosyncrasies. ${ }^{208}$ On the other hand, in order to be successful, a mediation program must account for the pre-mediation process, such as determining a case's suitability for mediation.

Finally, the preference expressed in the German program is for mediations face-to-face and their proposal to reduce the cost of mediations, is to conduct them in a one weekend block whenever possible. This should enable the process to meet the 1980 Hague Convention deadline, i.e. to have a final resolution within six weeks of commencing a Hague case but we doubt about the real possibility and true suitability. Definitely, time is very important; time for build confidence between mediators and clients and among clients, time to work o a wide agenda because in those mediation sessions it is necessary to talk about the return or not of the child and connected deals such as custody, place of residence, child support/maintenance, holiday arrangements, contact with grandparents/other relatives, schools, the child learning language skills, religion, travels, etc. ${ }^{209}$

Notwithstanding the German profile described earlier, there is a tendency lately that involves a strategy in which being selected as a mediator, depends on how closely that person is aligned with a case and the parents involved, how the mediator can structure the process to build trust between the parents and allow for the left behind parent to see his or her child, when and how to involve other people in the process, where the mediation will occur, whether technology must or should be used to conduct mediation at a distance through On Line Dispute Resolution; all this to carry out a successful International Family Mediation case.

repatriation) until a final decision about child custody and visitation can be made. This decision can also be negotiated in mediation proceedings" it mentioned, for instance, bi-national projects with Germany. Paul, supra n. 63, 43.

208 Paul, supra n. 63, 43.

209 Honorable supra n. 203, 50-51. http: / / www.hcch.net/uploadnews2007.pdf. 
The United Kingdom, through a non-governmental organization, Reunite International, completed a pilot mediation program in 2006 within the timeframe of the 1980 Hague Convention. ${ }^{210}$ The mediation took place approximately in a two day, face-to-face ${ }^{211}$ in the United Kingdom with a maximum of three hours with two independent mediators and an interpreter if it was required. "If an agreement was reached, the mediator memorialized it in a Memorandum of Understanding and presented it to the parties so that they could have their legal counsel reduce the Memorandum to a Consent Order in the United Kingdom and attempt to register or mirror that Consent Order in the other jurisdiction”. ${ }^{212}$ Currently, Reunite International, with this positive experience, offers mediation services in cross-border family disputes dealing with fundamental matters such as: security, speed, international acceptability, accessibility, incentive, expertise, and enforceability, ${ }^{213}$ where the use of ODR is postponed.

In Quebec, Canada, since September 1997, ${ }^{214}$ the court runs a mediation program at little cost to the parents, even international parental child abduction cases and cross-border family matters for mediation. The law came into force, allowing couples with children to obtain the services of a professional mediator during the negotiation and settlement of their application for separation, divorce, dissolution of the civil union, child custody, spousal or child support, or the review of an existing decision.

In Canada as well, the Mediate British Columbia Society, the largest not for profit mediation organization in British Columbia, has two projects, one

210 Reunite International Child Abduction Centre, Mediation in International Parental Child Abduction: The Reunite Mediation Pilot Scheme 14 (2006), http://www.reunite.org/ edit/files/Library-reunite Publications/MediationReport.pdf.

211 This pilot program did twenty-eight cases and only two cases was done or mediated by telephone. Reunite International Child Abduction Centre, Mediation in International Parental Child Abduction: The Reunite Mediation Pilot Scheme 14 (2006), http: / /www.reunite.org/ edit/files/Library-reunite Publications/MediationReport.pdf, p. 14

212 Kucinski, supra n. 116303.

213 With the "enforceability" “... Particular attention needs to be paid to ensure the agreement or order is sufficiently formed and understood, to prevent it being ignored in a foreign jurisdiction and to avoid unnecessary litigation. In England and Wales, Reunite is undertaking the setting up of a mediation scheme, with a practical pilot scheme, to take into account all of the foregoing concerns...”. Hutchinson, supra n. 98, 152.

214 http://www.justice.gouv.qc.ca/english/publications/generale/mediation-a.htm. 
of this is the Distance Mediation Project ${ }^{215}$ "explore the mediation of family disputes using communication technologies and was aimed at helping people who are separating or divorcing who find it difficult to communicate in person because of distance or conflict"; 216 the other project managed by Mediate BC Society is the Child Support Eligibility Mediation Program (CSEMP) that employs "non-traditional" modes of mediation, that is, not face-to-face, and explores the use of mediation in resolving maintenance issues for children over the age of $19 .{ }^{217}$

In Latin America a few states, such as Argentina, Brazil, Ecuador, Paraguay and Peru report that they are already mediating international parental abduction cases. ${ }^{218}$ In 2004 the Latin American Judges' Seminar on the 1980 Hague Convention on Civil Aspects of International Child Abduction met in Mexico ${ }^{219}$ to discuss ways to improve regional operation of the 1980 Hague Convention an had produced a number of conclusions and recommendations designed to enhance the implementation and enforcement of member states' obligations under the convention. ${ }^{220}$ Events such as this, fostered the establishment of a regional judicial/Central Authority network, regional expansion of the International Child Abduction Database (INCADAT) ${ }^{221}$ and creation of "The Judges'Newsletter" 222 Likewise, the proposal to create a

215 WwW.mediatebc.com.

216 Matsuno, Y., "Bridging Culture and Distance through Mediation: Innovative Projects and Approaches from Canada”, Recovery of Maintenance in the EU and Worldwide, Heidelberg, 5-8 March, 2013. Abstract.

217 Idem.

218 Zawid, supra n. 17, 13-14.

219 The Seminar was attended by Judges, Central Authority Officials and other experts from Argentina, Brazil, Canada, Chile, Colombia, Costa Rica, Dominican Republic, Ecuador, El Salvador, Guatemala, Mexico, Nicaragua, Panama, Paraguay, Peru, Spain, Untied States o America, Uruguay, and Venezuela as well as the Organization of American States, Inter-American Children's Institute, International Centre for Missing and Exploited Children, American Bar Association, Latin American Law Initiative Council, Texas-Mexico Bar Association and the Law School of Instituto Tecnológico de Estudios Superiores de Monterrey.

220 http: / / www.hcch.net/uoload/monterrey2.pdf.

221 A great effort of the Hague Conference practically without any resources, though some authors question its efficiency. C Bruch, "The Hague's Online Child Abduction Materials: A Trap for the Unwary", 44 Family Law Quarterly, 2010, pp. 65-82.

222 Arcaro, T., "Creating a Legal Society in the Western Hemisphere to Support the Hague Convention on Civil Aspects of International Child Abduction", The University of Miami InterAmerican Law Review, 2008, p. 125. 
new legal society in the Western Hemisphere to support operation of the Hague Abduction Convention is premised on a collaborative model of regional participation, ${ }^{223}$ where implementation of ODR has not been ruled out. $^{224}$

As expressed earlier, in 2005, the United States designated as Central Authority on Hague international parental abduction disputes, the United States Department of State's Office of Children's Issues, and agreed to engage in a bi-national pilot mediation scheme with Germany with BundesArbeitsgemeinschaft fur Familien-Mediation (BAFM), but to date, the United States has neither implemented nor funded a formal international parental kidnapping mediation program. Only, a Virginia non-profit organization, the NCMEC, offers parents involved in international parental kidnapping disputes the option to mediate, and attempts to secure volunteer mediators and attorneys for indigent parents. ${ }^{225}$ Several conferences have taken place in the U.S. and one important conclusion has been reached: to develop a series of "Best Practices and Protocols" to guide mediators in international child abduction, maybe through bi-national pilot programs. ${ }^{226}$

The United States Department of State, Office of Children's Issues, acting as a Central Authority, expresses that if you are a parent whose child has been taken from the United States to another country in violation of their parental rights they offer many services to search solutions for those cases, among them, those allowing settling out of court such as mediation, used as a preventive measure, where the parents may be able to resolve a custody dispute before one parent takes drastic action and abducts the child to another country. Mediation in child custody disputes is a facilitated discussion between two parents that focuses on helping the parents reach an agreement acceptable to both parties. ${ }^{227}$

223 Ibidem, pp. 109-138, specially p. 132.

224 It is relevant to point out the direction taken by reforms, in this case domestic ones, as is the case of reforms published by the "Gaceta Oficial del Distrito Federal" in june 19, 2013 regarding Mexico's Federal District Alternative Justice Law about implementation of ODR in mediation. González Martín, Nuria and Navarrete Villareal, Víctor M., “Comentarios a las reformas de 2013 en materia de mediación en el Distrito Federal”, TSJDF, 2013 (in print).

225 Alanen, supra n. 32, 63. About the efforts to develop an international family abduction mediation program in the United States, See Zawid, supra n 18, 16-17.

226 Zawid, supra n. 17, 17-18.

227 http://travel.state.gov/abduction/about/whatsnew/whatsnew_3859.html (march 21, 2013). 
As expressed earlier, the peculiar situation of the United States and Mexico has become especially important because many of the cases involving indigent parents who are unable to travel for reasons of cost or immigration restrictions ${ }^{228}$ therefore the implementation of best practices will be a key tool ${ }^{229}$ where the trend is the implementation of ODR.

\section{CONCLUSIONS}

From the overview offered about the contents and practical application of the 1980 Hague Convention, it is apparent that there is a need for interaction and complementation between regulatory techniques found in Hard Law — International Treaties, such as the 1980 Hague Convention — and Soft Law - Non binding instruments such as the Guide on Good Mediation Practices-.

The new realities in which family relations can be involved, call for the search of alternative solutions to the traditional judicial way. Definitely the foundation or motivation for the use of mediation is the increase of family conflicts with the intent to:

1) Guarantee healthy relationships within the family group, always looking for the Child's Best Interest.

2) To resolve conflicts in the most satisfactory way for all parties, taking into consideration that such relationships, when children exist, must remain in the future.

3) To Implement a mediation method searching permanently for the constant improvement of communication among all family members. Mediators must be trained and educated in International Family Mediation, with additional, mediation specific techniques - linguistic, cultural, ODR...- pursuing a prioritary and unmistaken goal such

228 Kucinski, supra n. 21, 84.

229 "Most recently, an American Bar Association task force began debating the topic, and will propose conclusions and recommendations for best practices within the United States", Idem. Also see the work the American Bar Association, as well as the International Academy of Matrimonial Lawyers — with the collaboration with the Global Justice Initiative (GJI) www.globalinitiative.org. 
as the Child's Best Interest, allowing mediators to create the most effective and efficient tools for dispute resolution and to promote a more open and less confrontational relationship among the parents. ${ }^{230}$

Many are the challenges entailed by International parental child abduction as well as of mediation and its connection with PIL - cooperation, conflict of laws, migration, criminal penalties, among others - . In this sense, we highlight that within the international community, the implementation of mediation programs is perhaps confronted with additional challenges arising from multiple jurisdictions, the lack of uniformity of the titles, norms and laws. ${ }^{231}$

Equally complex is handling meditation in cases of domestic violence; its use and mostly the abuse of its allegations as a way to obtain an exception for children return. As well, a debate has been raised by circumstances where mediation was not granted in cases of domestic violence, since individuals who suffer this situation should not experience a double discrimination, that is, being a victim and not a having access to an ADR process.

Regarding the use of technology to develop On Line Mediation or ODR, open and necessary debates are taking place. All the advantages and disadvantages of such ODR within the context of International parental child abduction seem to lead to the conclusion that a hybrid mediation model ${ }^{232}$ must be sought, ${ }^{233}$ something like the German model described previously. A hybrid meditation model would allow mediators to use face to face mediations - when conditions permit - as well as Online mediation. However, caution must be exercised since each case has its own peculiarities. No two cases can be mediated in the same way. The inclusion of such a technique in the Guide of Good Practices in Mediation, is by all means, a good sign in accordance with the quest for communication required by ADR.

230 Cunha, supra n. 179, 179.

231 Kucinski, supra n. 116, 306.

232 Pawlowski, supra n. 72, 311-312.

233 Including "some hybridity: Human Technology is crucial for many disputes in Verdonschot, Jin Ho, Power Point "The Future of Courts: A New Procedure for Neighbor Disputes in the Netherlands" in Resolving our Differences in the 21 $1^{\text {st }}$ Century: A Conference on Online Dispute Resolution, Stanford Law School, April 19, 2013”. http://www.hiil.org or http://www.innovat ingjustice.com. 
Definitely, analyzing pros and cons of mediation, promoting mediation as an alternative means for peaceful resolution of controversies as well as highlighting its potential for international parental child abduction, represent a starting point to draw the attention of scholars towards the need to intensify research on this subject.

The goal is to be able to conduct substantial and meaningful research in connection with such vast and complex topics, both from a theoretical and a practical perspective, particularly between the two countries, and always bearing in mind the Child's Best Interest. It is of utmost importance to do so within a framework that coherently encompasses all aspects of Alternative Dispute Resolution, as well as research experience of the proposed subject. 